\title{
Is Accounting a Miserable Job?
}

March 2019

\begin{abstract}
Popular culture portrays accounting as a miserable job. Accounting research evaluating the boring "beancounter stereotype" argues that it is wrong and costly because it reduces the appeal of accounting to high quality students and exacts a psychological toll on accountants who are thus stereotyped. In this study, we empirically test the basic question: is accounting a miserable job? We use data from a variety of sources that enable us to measure workplace misery and model it as a function of work tasks and personal characteristics of workers across occupations. We find that accounting work is particularly sedentary, rigid, repetitive, constrained, and rulescentric; characteristics that are consistent with the accounting stereotype and that prior work outside of accounting has shown are associated with workplace misery. However, we find that accounting is not a miserable job. In univariate and multivariate tests, we find that accounting has misery values that are either near the average or are better than average for comparison jobs. This apparent paradox could be a positive consequence of accounting stereotypes, which may facilitate the matching of potentially miserable work with people who are most prepared to tolerate it. Indeed, we present longitudinal evidence suggesting that accounting attracts people with personalities suited to repetitive and rules-centric work and who have psychosocial histories that make them robust to stress. Workplace misery is costly to workers, employers, and society and accounting stereotypes have value if they facilitate informed career selection.
\end{abstract}




\section{INTRODUCTION}

“...our experts describe you as an appallingly dull fellow, unimaginative, timid, lacking in initiative, spineless, easily dominated, no sense of humour, tedious company and irrepressibly drab and awful. And whereas in most professions these would be considerable drawbacks, in chartered accountancy they are a positive boon." John Cleese ${ }^{1}$

Accounting work has long been portrayed in popular culture as boring, rigid, and monotonous (Allen 2004, Beard 1994, Richardson et al. 2015, Smith and Briggs 1999, Smith and Jacobs 2011, Warren and Parker 2009). A branch of accounting literature argues that such stereotypes are costly to the profession because they reduce the number, quality, and diversity of people selecting into accounting careers (Baldvinsdottir et al. 2009, Beard 1994, Briggs et al. 2007, DeCoster and Rhode 1971, Friedman and Lyne 2001, Jeacle 2008, Smith and Briggs 1999), and that accounting careers are more interesting and compelling than the stereotypes suggest (Belski et al. 2003, Chen et al. 2012, DeCoster and Rhode 1971, Jeacle 2008, Warren and Parker 2009). However, other accounting literature suggests that accounting jobs are miserable. A majority of accounting educators and practitioners would not major in accounting if they "were completing their education over again" (Albrecht and Sack 2000, Ch. 4) and CPA firms have exceptionally high employee turnover (CPA Journal 2018). These problems are potential consequences of a widespread "burnout culture" in accounting that, in the early 2010s, caused "crisis level attrition" and a "rebellion" among junior staff at PwC (Nusca 2018, Purtill 2018), and of a mismatch between the personality traits that lead to success in accounting degree programs and those that lead to success in accounting firms (Briggs et al. 2007). Whether accounting is a miserable job is an empirical question that has not been carefully evaluated

\footnotetext{
${ }^{1}$ From The Vocational Guidance Counsellor (Chapman et al. 1989, 124).
} 
previously. ${ }^{2}$ In this study, we model workplace misery across occupations as a means of testing whether accounting is particularly miserable relative to available alternatives. Our evidence suggests that accounting is not a miserable job and, by some measures is significantly less miserable than other jobs and less miserable than would be expected given its characteristics.

Workplace misery is associated with a variety of costs to employers and workers including low productivity and high turnover (Cordes and Dougherty 1993, Jones et al. 2010, Kalbers and Fogarty 2005, Shirom 2003), higher incidence of depression (Brenninkmeyer et al. 2001), suicidal ideation (Dyrbye et al. 2008), coronary heart disease, and stroke (Kivimaki et al. 2015, Toker et al. 2012). Together, these personal and occupation-level costs represent a significant social burden. The World Health Organization estimates that unipolar depressive disorders are the $3^{\text {rd }}$ most costly disease globally and that self-inflicted injuries are the $20^{\text {th }}$ (WHO 2004), and argues that workplace psychosocial factors are significant environmental contributors to both depression and suicide (Leka and Jain 2010, Prüss-Üstün and Corvalán 2006). In the United States, Goh et al. (2015) estimates that about 120,000 deaths and 5\%-8\% of healthcare costs a year may be attributable to workplace misery. ${ }^{3}$

Workplace misery manifests in many ways and there are theories linking it to a wide array of causes. To make our empirical evaluations of misery in accounting as exhaustive as possible, we evaluate it in three settings, each of which enable us to measure misery and its potential causes in distinct ways using large samples of random Americans. In each of these settings, we compare accountants against other workers and also against a subset of workers more closely matched with accountants in terms of education.

\footnotetext{
${ }^{2}$ Misery is "a state of suffering and want that is the result of poverty or affliction" (https://www.merriamwebster.com/dictionary/misery). In this study, we use "workplace misery" to refer to suffering that is the result of workplace afflictions.

${ }^{3}$ Estimates for other countries are somewhat smaller, but still economically significant (Hassard et al. 2017).
} 
Our first setting is a person-level panel of random Americans taken from the General Social Survey (GSS) covering the years 1973 to 2016. The GSS sample is relatively large (about 350 accountants and 35,000 other workers) and enables us to produce our most statistically precise estimates of the relative misery of accountants. Our univariate tests show that accountants are less miserable than others when misery is measured using job dissatisfaction and unhappiness with life. These differences are large and statistically significant relative to all other workers in the GSS but are not significant relative to other college-educated workers. When we model workplace misery as a function of work, demographic, and psychosocial variables, we find that accountants are statistically significantly less likely to be unhappy than others even after considering controls. This suggests that accountants are less miserable than would be expected given their work and personal characteristics. We find no evidence that accountants are relatively miserable in any of our GSS tests.

Our second setting is an occupation-level cross-section in the 2000s which we assemble from the $\mathrm{O}^{*} \mathrm{NET}$ database and other sources. The distinctive value of this setting is that it enables us to measure more job dimensions than our other settings or any setting in prior research, and to model occupation-level suicide rates, which we measure with proprietary data we obtain from the U.S. Centers for Disease Control and Prevention. Our suicide rate estimates should be regarded as exploratory because of data limitations. Despite the data limitations, we believe our suicide rate tests are worth pursuing because suicide is a manifestation of workplace misery that has recently received significant attention in many fields (DeAngelis 2011, Sottile 2016, Stanley et al. 2016, Tomasi et al. 2019, Tribe 2018, Valentine 2017) and has not previously been modelled in a cross-occupation setting as a function of work characteristics. We find that, consistent with stereotypes, accounting work is relatively repetitive, rules-bound, 
sedentary, affords workers little decision latitude, and demands little creativity, characteristics that prior research has shown are associated with workplace misery (Freudenberger 1974, 1975; McClean and Wilburn 1991; Melamed et al. 1995; WHO 2010). However, in terms of job dissatisfaction, unhappiness, and a measure of poor mental health, accountants are less miserable than other workers in this setting as well. Our measure of suicide rates is higher in accounting than average, but we believe this is likely a consequence of mismeasurement because accountants are unusually easily identified in the suicide database. In addition, we again find that accounting's observed levels of misery are consistently lower than predicted by our occupationlevel models, consistent with less misery in accounting than expected given its characteristics.

Our final setting is a person-level longitudinal sample taken from the National Longitudinal Study of Adolescent Health (Add health) characterizing a random cohort of about 3,300 Americans (including 39 who became accountants) born between 1976 and 1984. Waves of data collection in Add health cover adolescence through adulthood, and enable us to measure a number of psychosocial predictors of mental health including personality, substance abuse, social support, childhood mental health, and abuse during childhood. We have relatively few accountants in Add health, and our misery estimates are less precise than in our other settings. Our Add health misery measures are job dissatisfaction, depression, a measure of stress, and suicidal thoughts and we find that accountants values for these measures are either statistically indistinguishable from average or significantly below average. We find that accountants have a number of psychosocial characteristics associated with good mental health and resilience, including low rates of substance abuse as adults and, as children, relatively low rates of depression, good relationships with parents, and less experience with physical and sexual abuse. ${ }^{4}$

\footnotetext{
${ }^{4}$ In this study, we focus primarily on stereotypes of accounting work, but there is a related set of stereotypes of accountants themselves (illustrated by John Cleese in the opening quote). The stereotypical accountant is shy,
} 
These traits are likely protective against workplace misery and could explain why accountants are less miserable than predicted in our other settings, where we cannot measure many of these psychosocial traits. Accountants also have conscientious personalities at high rates, which is associated with meticulousness and attention to detail, traits that are likely assets in accounting.

Existing research on occupation-level misery overwhelmingly uses relatively small convenience samples of people from one occupation at a time. The greatest strength of these studies is that they typically collect data using study-specific instruments that enable them to measure their misery proxies with great precision. However, this approach is not well suited to cross-occupational comparison because of non-standardized sampling methods and differing misery covariates. Three prior studies compare workplace misery in accounting to other occupations using a popular job "burnout" measure. None of these studies includes statistical controls for differences in job characteristics and the results are mixed, with burnout among public accountants being relatively high after busy season (Sweeney and Summers 2002) and accountants' burnout being near or below average in more general circumstances (Fogarty et al. 2000, Figure 2; Johnson et al. 2005).

To summarize, we show that accounting is a job that, because it is sedentary, rigid, and repetitive, has the potential to produce high rates of misery. Yet it does not, at least not according to accountants. A potential explanation is that people choose accounting careers from a menu of options, likely with foreknowledge of accounting stereotypes (Haslam et al. 1998). Given that accounting stereotypes are accurate to a degree, they may protect against misery by facilitating informed career selection. This explanation is supported by two prominent theories of workplace

prudish, obsessive, gullible, humorless, criminal, submissive, risk-averse, and uncreative (Baldvinsdottir et al. 2009, Beard 1994, DeCoster and Rhode 1971, Smith and Briggs 1999). Our Add health evidence supports the accuracy of some of these stereotypes (shy and conscientious), but does not address many others. 
misery. The first posits that misery is a function of the degree of person-environment fit (Caplan 1987). If people believe accounting stereotypes are accurate, those who are relatively tolerant of rigid and monotonous work should be more likely to pursue accounting careers, to find that their accounting job is a good fit and, therefore, to experience relatively little workplace stress. The second posits that misery is a consequence of initial illusory idealism about a job followed by disillusionment after exposure to work's realities (Freudenberger 1974, 1975). Given evidence that students selecting into accounting degree programs are particularly unlikely to choose accounting because it is interesting to them (Madsen 2015), accountants may be protected against disillusionment because they were never illusioned to begin with. These explanations have the practical implication that accounting stereotypes likely have significant upsides for accountants and their employers, and efforts by the profession to counter these old stereotypes, if they were successful, would likely have negative unintended consequences (Briggs et al. 2007, Jeacle 2008).

In the next section, we describe related literature and develop our hypothesis. We then describe our data and models in Section III. In Section IV, we discuss our results, and in Section $\mathrm{V}$, we discuss conclusions.

\section{BACKGROUND AND HYPOTHESIS}

There is a large interdisciplinary literature evaluating workplace misery that collectively shows it is associated with a broad array of potential causes including sets of job tasks, demographic variables, the social environment at work and elsewhere, and personality traits. Prior literature typically examines subsets of these causes in isolation (Mark 2008) with the goal of developing and testing organizational theories and evaluating misery outcomes most directly relevant to firm managers. This literature is large and shows that misery is associated with 
outcomes like low satisfaction with elements of the job, low commitment to the organization, absenteeism, and turnover (Cordes and Dougherty 1993; Freudenberger 1974, 1975; Fogarty et al. 2000; Karasek 1979; Shirom 2002; West et al. 2016). While our study is related to this literature, our goal is not to test organizational theory but to provide replicable, large-sample evidence to inform discussions of accounting misery. We use prior literature to 1) define misery in a way that is appropriate for our setting, 2) identify a large set of potential causes of workplace misery, 3) identify measures of misery and their causes that are related to those in prior literature and are available across large samples of occupations, and 4) develop our hypothesis.

Prior research uses various definitions and measures of misery. We refer to these collectively using our own umbrella term, "workplace misery." The typical approach in prior literature has been to collect data from a convenience sample of workers in a given occupation or organization using psychometrically validated measures of misery including the Perceived Stress Scale (Cohen et al. 1983, Karam et al. 2012), the role ambiguity and role conflict scales (Rizzo et al. 1970), the Maslach Burnout Inventory (Maslach and Jackson 1981), and the Center for Epidemiologic Studies Depression Scale (Radloff 1977), and examine their associations with various employment outcomes. While some of these misery measures are available in Add health, most are not available in any of our settings. We, therefore, use a broader definition of workplace misery than prior literature, and measure it using both misery proxies and outcomes of misery identified previously.

Theory and evidence link misery to a wide array of causes, but a consensus has emerged recently about the general theoretical forces that explain it. Specifically, workplace misery is an outcome of the interaction between external stressors in a person's environment, individual differences shaping a person's interpretations of, and reactions to, these stressors, and the social 
resources at work and elsewhere a person can draw on to cope with stressors (Briner et al. 2004; Cooper et al. 2001, 16; Cox et al. 2000, 11; Mark and Smith 2008). Generalizing from this literature, we model workplace misery as a function of work and personal stressors and personal characteristics that shape a person's capacity to cope with stress. Covariates of workplace misery we consider are of three types: characteristics of work tasks and environments, demographic characteristics of workers, and psychosocial characteristics of workers.

Early models of workplace misery focused on job characteristics, which are convenient to measure in work settings, are sources of workplace misery that are most likely controllable by employers, and are, therefore, potentially fruitful targets for interventions designed to reduce workplace misery. A prominent example of a work-oriented model is Karasek (1979), which develops the demand-control model of workplace "strain." It posits that workplace misery is a joint function of the demands of the job, which are stressors that can contribute to misery, and the discretion the worker has when facing those demands, which can protect against misery. Misery, in this model, is a consequence of stressful work demands combined with limited decision latitude. Karasek's $(1979,289)$ measures of stressful work demands include workload, work pace, time pressure, and conflicting demands, and measures of control include high skill level, on the job learning, creativity, freedom to make decisions, and involvement in decision making. Figure 1 is a scatterplot we produce using Add health data illustrating the relationship predicted by Karasek's (1979) model between greater decision latitude (measured in Figure 1 using a factor describing the extent to which a person's work is of high status on the $\mathrm{x}$-axis) and workplace misery (measured in Figure 1 using a depression scale on the y-axis). Each grey dot represents a non-accountant and each black square represents an accountant. Figure 1 shows that 
there is a strong negative association between high status work and depression. It also shows that accountants, on average, have relatively high status and relatively low depression scores.

The demand-control model remains influential, but there has been increasing recognition that workplace misery is not simply an outcome of stressful work conditions; rather, it is a function of interactions between workplace conditions and worker psychology with the consequence that two workers can respond to identical conditions differently (Briner et al. 2004, Mark and Smith 2008). New models of workplace misery have proliferated that incorporate individual differences expected to influence worker perceptions of stress and ability to cope, which include pay, the social climate at work, opportunities for career advancement and personal development, and conflicts between work and home (Mark and Smith 2008, Sparks and Cooper 1999, Veldhoven et al. 2005). This acknowledgment of the importance of individual demographic and psychosocial differences is meaningful for our study because both are known drivers of general wellbeing and career selection. Demographic and psychosocial characteristics are difficult to study using the traditional single-occupation convenience samples common to job misery research. In the case of demographic variables like education, within-occupation variation is often far more limited than between-occupation variation. In the case of psychosocial measures, there is a high risk of simultaneity bias, as it is not possible to disentangle psychological causes of misery from psychological consequences of misery. Our crossoccupation settings enable us to deal more effectively with both of these problems. We can measure cross-occupation demographic variation, add occupation fixed-effects to model withinoccupation variation, and, particularly in Add health, we can measure psychosocial variables that predate the career selection decision. 
Prior research on wellbeing and demographics shows that there is a positive association between life satisfaction and age (Sutin et al. 2013), marriage (Haring-Hidore et al. 1985), education (Witter et al. 1984), and income (Kahneman and Deaton 2010). ${ }^{5}$ Women are more likely to be diagnosed with depression (Girgus and Yang 2015), as are adults who had lower socioeconomic status as children (Wickrama et al. 2009). Divorce is also associated with lower wellbeing in the short- and long-term (Lucas 2005). Research on psychosocial variables shows that personality (Parkes 1994, 116), social support (Grav et al. 2011), substance abuse (Swendsen and Merikangas 2000), and childhood stressors such as bullying and physical or sexual abuse (Oshio et al. 2013) are associated with wellbeing. Our empirical models, described in the next section, are composed of proxies for the subsets of these work, demographic, and psychosocial constructs for which we can identify reasonable proxies in each of our settings.

Our hypothesis follows from the accounting literature on stereotypes and job dissatisfaction summarized in Section I. The stereotype that accounting is a rigid and monotonous job populated by boring, obsessive people is observable in movies (Beard 1994 Cory 1992), television and literature (Cory 1992, Smith and Briggs 1999), newspapers and magazines (Friedman and Lyne 2001), and comedy (Bougen 1994) and likely propagates, in part, through these media. ${ }^{6}$ Stereotypes are common knowledge within cultures and are likely widespread (McGarty 2002, 5-6), and there is specific evidence that the accounting stereotype is common knowledge among college students (Allen 2004, Cory 1992) and operations managers (Friedman and Lyne 1995). If accounting stereotypes are accurate, there is reason to expect that

\footnotetext{
${ }^{5}$ Khaneman and Deaton (2010) evaluate the association of income with measures of life evaluation and emotional wellbeing. They find, in a large sample of Americans, that emotional wellbeing plateaus at an annual income of about $\$ 75,000 /$ year while life evaluation does not plateau, but continues increasing as income increases. Our measures of job satisfaction and unhappiness correspond more closely to life evaluation measures than emotional wellbeing measures.

6 There is some discussion in this literature of an "accountants are criminals" dimension to the stereotype (Beard 1994, Jeacle 2008, Richardson et al. 2015).
} 
accounting is a miserable job given existing evidence demonstrating a positive association between rigid, repetitive, sedentary, and uncreative work and measures of workplace misery (Freudenberger 1974, 1975; Karasek, 1979; McClean and Wilburn 1991; Melamed et al. 1995; WHO 2010). Prior literature also shows evidence of misery among accountants in the form of low job satisfaction (Albrecht and Sack 2000, Ch. 4), and high turnover (CPA Journal 2018, Nusca 2018, Purtill 2018).

On the other hand, there is another body of theory and evidence that suggests that accounting may not be a miserable job. People who select into accounting have traits that likely protect them against misery. First, there is evidence of good fit between the nature of accounting work and the personalities of students who pursue accounting degrees. Accounting degree programs attract high concentrations of people with "STJ" Myers-Briggs personalities, who tend to be "hardworking, exacting, thorough and reliable," qualities that are "required by the accounting profession" (Briggs et al. 2007, 534). Second, accountants are likely protected against disillusionment, a prominent theoretical cause of career burnout (Freudenberger 1974, 1975), because they choose accounting for realistic reasons. Specifically, students who pursue accounting degrees tend to be interested in earning money and having stable jobs, while they are particularly unlikely to study accounting because it interests them, and accounting delivers on these expectations (Leiby and Madsen 2017, Madsen 2015). Finally, literature on accounting stereotypes written by academic and practitioner accountants either directly argues or implicitly assumes that negative stereotypes about accounting are not accurate (Belski et al. 2003, Chen et al. 2012, DeCoster and Rhode 1971, Jeacle 2008, Warren and Parker 2009), which suggests, at a minimum, that the accountants producing this literature do not believe that accounting is a miserable job. 
Together, existing evidence does not suggest a clear directional hypothesis about whether accounting is a miserable job. Accounting work has attributes that are associated with misery in non-accounting settings and non-accountants tend to view accounting work as miserable. But accountants tend to have attributes that may protect them against the potential harms of these job characteristics, and accountants themselves assess accounting work more positively than nonaccountants. This leads to our hypothesis:

$\mathrm{H}$ : Accountants experience workplace misery at different rates than workers in other occupations.

In the next section, we describe our data sources and how we measure the constructs described in this section using data from them.

\section{DATA AND MODELS}

Our data come from three primary sources, with a few variables coming from additional sources. Our first primary data source is the public use version of the General Social Survey (GSS), a project of the National Opinion Research Center at the University of Chicago (Smith et al. 2018). ${ }^{7}$ It is an individual-level survey describing demographics, attitudes, and behaviors of random samples of Americans in most years since 1972. Our second primary data source is O*NET, which contains occupation-level data describing validated measures of characteristics of all U.S. jobs and is sponsored by the U.S. Department of Labor and Employment and Training Administration. ${ }^{8}$ The third is the public use version of Add health, an individual-level

\footnotetext{
${ }^{7}$ http://gss.norc.org/.

${ }^{8}$ See https://www.onetcenter.org/db releases.html and https://www.doleta.gov/.
} 
longitudinal study focused on measures of health and wellbeing that follows a cohort of Americans who were in grades 7-12 during the 1994-1995 school year (Harris 2009). ${ }^{9}$

We collect additional variables from other data sources. The first is IPUMS-CPS, a collection of individual-level data from the Current Population Survey, which is produced by the U.S. Census Bureau and U.S. Department of labor and characterizes demographic and labor market characteristics of individuals and households from the 1960s to the present (Flood et al. 2018). ${ }^{10}$ The second is IPUMS-ATUS-X, and individual-level time use survey containing data since 2003 describing how random Americans spend their time (Hofferth et al. 2017). ${ }^{11}$ The third is the Occupational Employment Statistics database, a project of the U.S. Department of Labor's Bureau of Labor Statistics, which characterizes occupation sizes and average earnings at the state-year level. ${ }^{12}$ The final dataset is proprietary and characterizes individual-level suicides by state-year from 2003 to 2015 from the Restricted Access Database of the National Violent Death Reporting System of the Centers for Disease Control and Prevention. ${ }^{13}$ Except for the suicide database, all of the databases we use are available for download free of charge from the sources in the footnotes.

Our first empirical model (model 1) uses individual-level data from the GSS covering the years 1974-2016. During this 42-year window, we have data for 29 years due to missing variables or missing years in GSS. The advantage of this setting is that it enables us to measure many features of misery, job characteristics, demographics, and psychosocial characteristics of interest to us and contains relatively large numbers of observations. It is the setting that affords

\footnotetext{
${ }^{9}$ https://www.cpc.unc.edu/projects/addhealth.

${ }^{10} \mathrm{https} / / / \mathrm{cps}$.ipums.org/cps/.

11 https://www.atusdata.org/atus/.

12 https://www.bls.gov/oes/.

${ }_{13}$ https://www.cdc.gov/violenceprevention/datasources/nvdrs/index.html.
} 
us the most statistical power. We list our model 1 variable labels here. See the Appendix for additional variable detail:

- Misery proxies

- Job dissatisfaction and unhappiness.

- Job characteristics

- Accounting indicator, income in 1986 dollars, prestige, hours worked, long hours (indicator for over 55 hours), high school graduate, bachelor's degree, and master's degree.

- Demographic characteristics

○ Female, age, married, ever divorced, childhood income low, and childhood income high.

- Psychosocial characteristics

○ Close friends, close family, and weekly church.

We estimate models explaining each of our misery measures using all of our job characteristics, demographic, and psychosocial variables on two samples, one restricted to include only those working at least 10 hours a week, and the other restricted to include only those working at least 30 hours a week and who have at least a bachelor's degree. We estimate all models throughout this study using OLS, even though our dependent variables are dichotomous, counts, logged rates, and depression or stress scales, following the arguments in Angrist and Pischke (2009) because we believe that using OLS does not compromise the validity of our results while it simplifies their interpretation and exposition. ${ }^{14}$

Our second empirical model (model 2) uses occupation-level data from O*NET, GSS, IPUMS-CPS, IPUMS-ATUS-X, the CDC, and the OES. The distinctive value of this setting is that we can measure a very long list of job characteristics and we can use occupation-level suicide rates as dependent variables. We use O*NET version 20.1 from October of 2015. This analysis requires that we merge variables across databases that use different occupation classification schemes. O*NET features occupation-level data and uses an expanded version of

\footnotetext{
${ }^{14}$ We report information on the robustness of our results to different modelling choices in footnotes throughout the results section. In general, we find that our findings are not sensitive to this methodological decision.
} 
the Standard Occupation Classification system (SOC), in which some of the standard SOC occupations classified with six-digit codes (e.g. "13-2011: accountants and auditors") have been broken into multiple constituent occupations with eight-digit codes (e.g. "13-2011.01: accountants" and "13-2011.02: auditors"). Many of our other datasets use versions of the Census Bureau occupation classification system and feature individual-level data. The census bureau publishes "crosswalks" to facilitate merging SOC data with Census Bureau data, but these systems often feature differing levels of aggregation. Our merging procedure involves 1) for O*NET, aggregating all eight-digit SOC occupations into six-digit occupations by calculating equal weighted averages across eight-digit codes, 2) for GSS, IPUMS-CPS, and IPUMS-ATUSX, obtaining 4-digit census occupation codes and using Census Bureau crosswalks to identify matching six-digit SOC codes (where a match exists), and then aggregating individual-level information from the years 2002-2015 and from the states reporting suicide data to the $\mathrm{CDC}^{15}$ into SOC occupation-level data by calculating survey weighted averages of individual responses for each occupation (we drop occupation-level values calculated from fewer than 5 individuals), and 3) to facilitate matching with suicide rate data (described next), we further aggregate some six-digit SOC codes into more general occupation groups (we merge occupations representing various kinds of engineers, physicians, teachers, professors, therapists, and programmers into one broader occupational group for each of these categories) by calculating equal weighted averages across input occupations.

The CDC collects individual-level microdata describing suicides from 32 U.S. states and provided it to us in their National Violent Death Reporting System Restricted Access Database

\footnotetext{
${ }^{15}$ These states are: Alaska, Arizona, Colorado, Connecticut, Georgia, Hawaii, Illinois, Indiana, Iowa, Kansas, Kentucky, Maine, Maryland, Massachusetts, Michigan, Minnesota, New Hampshire, New Jersey, New Mexico, New York, North Carolina, Ohio, Oklahoma, Oregon, Pennsylvania, Rhode Island, South Carolina, Utah, Vermont, Virginia, Washington, and Wisconsin.
} 
(RAD). Individuals' current occupations are listed in RAD in a free-text field containing an occupational title that is not standardized. Matching these free-text occupations with SOC codes is a difficult process, which we attempt in several steps. We assemble two lists of SOC code job titles that we match against RAD free-text job titles iteratively. Our first set of SOC job titles come from a file distributed by the Bureau of Labor Statistics (BLS) that lists general and specific job titles by SOC code and our second set is hand collected (described below) ${ }^{16}$ Many of the BLS job titles are multiple job titles in a single field, a job title format that does not appear frequently in the RAD free-text job titles. We, therefore, split job titles from this file into simplified job titles by hand to improve the chances we can match them with RAD job titles (e.g. we convert "maintenance and custodian supervisor" to "maintenance supervisor" and "custodian supervisor"). We then perform preliminary matches of this SOC job title file with the RAD freetext occupation titles. ${ }^{17}$

After these preliminary matches, we find that a number of common job titles in the RAD data do not match an SOC job title. We manually categorize all unmatched RAD job titles that appear 10 or more times as 1) an unambiguous match with an SOC code we identify by searching the $\mathrm{O} *$ NET website for the RAD job title, 2) too vague to unambiguously match to a six-digit SOC occupation (e.g. "manager"), and 3) unmatchable because the text does not refer to a job (e.g. "unemployed"). After this process, we have our second SOC job title matching file. We use this file to categorize remaining unmatched RAD job titles as matching an SOC code,

\footnotetext{
${ }^{16}$ Available here https://www.bls.gov/soc/soc_2010_direct_match_title_file.xls.

${ }^{17}$ Whenever we match the CDC free-text occupation titles with one of our SOC code occupation title files, we identify matches in the following ways: 1 to 1 matches first, fuzzy token matches second (these perform well when word orders are different but the words match), and fuzzy bigram matches third (these perform well for spelling errors and word stemming differences). We perform these three types of matches on the original data files, and then repeat them using data files we have "cleaned" to make common abbreviations more uniform (e.g. "tech" is replaced with "technician") and to remove punctuation. We retain perfect matches and fuzzy matches with the highest similarity scores (90\% and above).
} 
vague, or unmatchable using our standard iterative matching procedure. Finally, we take special care identifying members of some professional groups, because we believe that they make particularly meaningful comparisons for accountants. These are physicians, engineers, social workers, psychologists, nurses, software developers, teachers, professors, and accountants.

The RAD database contains information about 137,085 suicides of people with 21,847 distinct job titles. We successfully match 54,518 suicides (40\%) with 4,733 job titles to an SOC code. We also identify 29,602 suicides (22\%) with 2,657 job titles that unambiguously do not represent jobs (many of these are unemployed) or represent military jobs, which are excluded from $\mathrm{O} *$ NET. The remaining suicides ( $38 \%$ of the total count) have ambiguous relationships with occupations. We are confident that 34,503 suicides ( $25 \%$ of the total) with 1,720 job titles are too vague to match to a six-digit SOC code. The remaining 18,462 suicides ( $13 \%$ of the total) with 12,737 idiosyncratic job titles are unmatched, and we are unable to determine why. Given the large number of vague job titles, interpreting our suicide rate data is difficult because they understate suicide rates in any occupation that is identified with an ambiguous title in the RAD dataset. To identify occupations that are likely missing significant numbers of suicides because of vague job titles in the RAD data, we perform another set of matches between our two sets of SOC job titles and our list of vague job titles from the RAD. This enables us to estimate how many suicides may be missing for each occupation because of vague job titles. When the fraction of vague suicides that could potentially belong to the occupation divided by the suicides unambiguously attributed to the occupation is $15 \%$ or greater, we exclude the occupation from our suicide tests. This procedure causes us to lose all management occupations because these very frequently match with vague job titles.

Titles of variables in model 2, with sources in parentheses, are: 
- Misery proxies

- Job dissatisfaction (GSS), unhappiness (GSS), days of poor mental health (GSS), and suicide rate (CDC RAD and OES).

- Job characteristics

- Average income (OES), proportion working long hours (O*NET), competitive pressure $\left(\mathrm{O}^{*} \mathrm{NET}\right)$, time pressure $(\mathrm{O} * \mathrm{NET})$, time off easy to get (GSS), work related travel (ATUS-X), job security (GSS), fair promotion (GSS), active learning $\left(\mathrm{O}^{*} \mathrm{NET}\right)$, on the job training $\left(\mathrm{O}^{*} \mathrm{NET}\right)$, free to make decisions $\left(\mathrm{O}^{*} \mathrm{NET}\right)$, adaptability $\left(\mathrm{O}^{*} \mathrm{NET}\right)$, repeat tasks $(\mathrm{O} * \mathrm{NET})$, standards $\left(\mathrm{O}^{*} \mathrm{NET}\right)$, creative thinking $\left(\mathrm{O}^{*} \mathrm{NET}\right)$, indoor $\left(\mathrm{O}^{*} \mathrm{NET}\right)$, sitting $\left(\mathrm{O}^{*} \mathrm{NET}\right)$, awkward positions $\left(\mathrm{O}^{*} \mathrm{NET}\right)$, physical activity $\left(\mathrm{O}^{*} \mathrm{NET}\right)$, and education requirements $(\mathrm{O} * \mathrm{NET})$.

- Demographic characteristics

- Percent male (GSS), average age (GSS), and percent divorced (GSS).

- Psychosocial characteristics

○ Religiosity (GSS) and gun ownership (GSS).

Our third empirical model (model 3) uses individual-level data from Add health. The distinctive value of this setting is that it enables us to measure additional psychosocial variables, including a number collected during adolescence. Model 3 variables are:

- Misery proxies

$\circ$ Job dissatisfaction, depression, stress scale, and suicidal thoughts.

- Job characteristics

- Accounting indicator, income in 2016 dollars, prestige, hours worked, long hours (indicator for over 55 hours), irregular work hours, free to make decisions, repetitive work, high school graduate, bachelor's degree, and master's degree.

- Demographic characteristics

- Female and family income in adolescence.

- Psychosocial characteristics

- Family interferes with work, work interferes with family, daily prayer, weekly church, close friends, excessive drinking, marijuana, drugs, neurotic personality, extraverted personality, conscientious personality, open personality, agreeable personality, depression in adolescence, suicidal thoughts in adolescence, suicide attempts in adolescence, family or friends suicide during adolescence, feel that friends care during adolescence, feel that parents care during adolescence, physical abuse during childhood, and sexual abuse during childhood.

\section{RESULTS}

Several of our data sources come from surveys with complex sampling designs. Using such data to make population-level inferences requires the use of statistical methods that account 
for the biases introduced by such designs. Throughout our study, all of our reported results come from procedures that account for survey design characteristics.

\section{Model 1}

Descriptive statistics for model 1 variables are in Table 1. Panel A shows information for all individuals who reported working for pay at least 10 hours a week, which we call our "all education" sample, and Panel B shows information for individuals who report working at least 30 hours a week and who hold at least a bachelor's degree, which we call our "college education" sample. In each panel, we display information for non-accountants next to information for accountants, as well as differences between mean values for these two groups and the statistical significance of these differences. Accountants are unusual relative to the all education sample, with significant differences between most values in Panel A. Our primary interest in Table 1 are the comparisons of job dissatisfaction and unhappiness values for accountants against non-accountants. Significantly higher or lower misery values for accountants would enable us to reject our hypothesis. We find that accountants are less likely than nonaccountants to report job dissatisfaction or unhappiness. These differences are large and statistically significant relative to the all education sample but smaller and statistically insignificant relative to the college education sample. Table 1 also shows that $30 \%$ of the accountants in our sample report that their highest degree is a high school diploma, $54 \%$ that it is a bachelor's degree, and $15 \%$ that it is a master's degree. Accountants are distinctive relative to non-accountants in both of our samples in that accounting has unusually high prestige scores. In general, accountants have much in common with others in the college education sample. 
Table 2 shows univariate correlations among our model 1 variables. ${ }^{18}$ Job dissatisfaction and unhappiness are positively correlated (0.17), consistent with people who are dissatisfied with their jobs being more unhappy with their lives. Both of our misery measures are significantly negatively correlated with income, prestige, and hours worked, and are significantly positively associated with childhood income low. There are positive and significant correlations among several of our variables that all relate to high status work, including income, prestige, higher education, and age. Married is also positively correlated with these "high status" variables.

Table 3 shows the results of estimations of several versions of model 1. For each of our misery measures, we estimate models using samples including all people working 10 or more hours a week (left-hand-side) and people working 30 or more hours a week who have at least a bachelor's degree (right-hand-side). In each of these groups, we estimate models that include as independent variables only job characteristics (columns 1, 4, 7, and 10), models including all of our model 1 variables $(2,5,8$, and 11$)$, and models including all model 1 variables and occupation and year fixed effects $(3,6,9$, and 12). We are most interested in the coefficients on the accounting variable, as these are informative about whether accountants have misery values that are not what the model predicts given the other independent variables. We find that, when job dissatisfaction is the dependent variable, none of the coefficients on the accounting term are statistically significantly different from zero. When unhappiness is the dependent variable, the coefficient on accounting is negative and significant in five of the six regressions, which signifies that accountants are less likely to report being unhappy than other workers, even after considering the model 1 job, demographic, and psychosocial characteristics.

\footnotetext{
${ }^{18}$ It is not straightforward to calculate significance levels for correlation coefficients calculated from survey data. We calculate significance levels using the method recommended here: https://www.stata.com/support/faqs/statistics/estimate-correlations-with-survey-data/.
} 
Job dissatisfaction and unhappiness are both dichotomous variables, and our model 1 regression coefficients are interpretable as changes in the probability a respondent will report experiencing these forms of misery. The -0.02 coefficient in column 4 of Table 3 signifies that accountants are $2 \%$ less likely to report being unhappy than non-accountants after controlling for other independent variables. Given a base rate level of unhappiness of $9 \%$ in the column 4 sample, this is a large effect. The model 1 regressions further show that workplace misery is consistently negatively associated with income, prestige, marriage, and weekly church attendance while it is positively associated with low income during childhood. Adding year and occupation fixed effects to our regression changes the magnitudes and statistical significance of some of the coefficients, but the changes are typically small, which suggests that the factors that explain variation in misery across occupations are the same as the factors that explain it within occupations. ${ }^{19}$

To summarize, in our first setting, we find that misery in accounting is lower than in other occupations in our sample, and is statistically significantly lower than in our "all education" sample. We further find that, when misery is measured using unhappiness, accounting has significantly lower levels of misery than predicted by our model.

\section{Model 2}

Descriptive statistics for model 2 are in Table 4 with comparisons against all occupations in Panel A and comparisons against occupations requiring some college education in Panel B. Job dissatisfaction and unhappiness are calculated using the GSS and are similar to values in

\footnotetext{
${ }^{19}$ We estimate our model 1 regressions using logit and find results that are similar to those reported. We could not estimate the column 9 model (job dissatisfaction with occupation fixed effects) because it failed to converge. The coefficients on the accounting terms are all negative. Statistical significance across the columns deviates in small ways from the reported results. The column 4 accounting coefficient changes from significance at the $p<0.05$ level to the $\mathrm{p}<0.10$ level. The column 6 coefficient changes from significance at the $\mathrm{p}<0.05$ level to significance at the $\mathrm{p}<0.01$ level. The column 10 and 11 coefficients, which a marginally significant using OLS, have p-values in our logit models that are slightly above conventional significance levels $(p=0.116$ and $p=0.154$ respectively).
} 
model 1 except that model 2 values come exclusively from a more recent period (2002-2015). In this setting, we add two misery measures, mental health bad and suicide rate. All of the misery measures except suicide rate are relatively low in accounting, falling between the $23^{\text {rd }}$ and $47^{\text {th }}$ percentiles. Suicide rate for accounting is in the $62^{\text {nd }}$ (Panel A) and $60^{\text {th }}$ percentiles (Panel B). Both mental health bad and suicide rate have distributions with long right tails. We log transform them both when modeling them in our model 2 regressions.

Accounting is, again, more similar to the more educated occupations in Panel B than to all occupations in Panel A. The greatest advantage of model 2 over the other models is that it enables us to examine a larger number of work characteristics, and these show that accounting is unusual relative to other occupations because it is exceptionally sedentary (physical activity in the $5^{\text {th }}$ and $11^{\text {th }}$ percentiles in Panels A and B respectively), standardized ( $97^{\text {th }}$ and $95^{\text {th }}$ percentiles $)$, repetitive $\left(90^{\text {th }}\right.$ and $92^{\text {nd }}$ percentiles $)$, and features little creativity $\left(41^{\text {st }}\right.$ and $14^{\text {th }}$ percentiles) or decision latitude (free to make decisions is in the $42^{\text {nd }}$ and $22^{\text {nd }}$ percentiles). Table 4 also shows that there is considerable variation in sample sizes across our variables. Variables calculated from $\mathrm{O}^{*}$ NET are available for about 517 occupations, from GSS are available for as many as 355 occupations (monthly church) and as few as 229 (promotions fair), from IPUMSCPS are available for 417 occupations, from IPUMS-ATUS-X for 503 occupations, and for suicide rates for 272 occupations. Regressions reported below use somewhat fewer variables than this because observations that have missing values for any of these variables are excluded.

We do not tabulate a correlation table for model 2 because it is a large model and is difficult to display, but, in untabulated tests, we find that many of our model 2 variables are highly correlated and multicollinearity makes it difficult to interpret the results of regressions that include them together. We perform a factor analysis on all of our independent variables and 
find that four factors explain $67 \%$ of their shared variance and also feature consistent associations with the independent variables that make the factors interpretable. Our model 2 regressions use these factors as independent variables instead of our raw independent variables to facilitate interpretation of the results. Results from our factor analysis are displayed in Table 5. Our factor analysis uses the iterated principal factors method and, Panel A shows, produces five factors with eigenvalues greater than 1 (a common rule of thumb cutoff for retaining factors). We retain only the first four of these factors because the fifth does not have a clear interpretation.

Table 5 Panel B shows that the first factor, which we call status, is strongly positively associated with a number of variables increasing with occupational status or prestige including income, education, freedom to make decisions, older age, long work hours, and competitive pressure, while it is negatively associated with physical activity. The second factor, which we call blue collar, is strongly positively associated with long work hours, work related travel, on the job training, physical activity, spending time in awkward positions, male, and gun ownership while it is strongly negatively associated with indoor and monthly church. The third factor, which we call repetitive, is strongly positively associated with time pressure, repeat tasks, and divorced while it is negatively associated with promotions fair. The fourth factor, which we call security, is strongly positively associated with job security and monthly church and negatively associated with time off easy.

Table 6 shows our model 2 regressions relative to all occupations (Panel A) and occupations requiring some college (Panel B). Each panel shows regressions as well as information about regression errors for accountants and the five occupations with the largest and smallest regression errors. We perform three regressions in each panel for each of our misery measures. The first includes all of our factor variables, the second includes only the status factor 
variable, and the third includes only income. Sample sizes are fairly small, varying from 30 occupations in the panel B suicide rate regressions to 338 occupations in the Panel A unhappiness regression in which income is the only independent variable. Table 6 shows that our factor variables explain a great deal of the variation in our misery measures, with R-squared values averaging $24 \%$ across these regressions. $\mathrm{R}$-squared values fall considerably in regressions with status or income as the only independent variables. Job dissatisfaction and unhappiness are occupation-level percentages, so coefficients in these columns are interpretable as the amount by which the percentage of occupation members reporting misery changes for a one unit change in our factors. The coefficient on status in column 1 of Panel A is -0.046 , which signifies that a one unit increase in the status factor is associated with $4.6 \%$ fewer occupation members experiencing misery. Mental health bad is the average number of days in a month that occupation-members report experiencing bad mental health, so, for example, the coefficient on blue collar in column 7 of Panel A of -0.132 signifies that a 1 unit increase in the blue collar factor is associated with 0.123 fewer days of poor mental health per month among members of the occupation. Suicide rate is the suicide rate per 1,000 workers. The coefficient on blue collar in column 10 of Panel A of 0.856 signifies that a one unit increase in an occupation's blue collar value is associated with 0.856 more suicides per 1,000 workers.

Information on regression errors at the bottom of Panels A and B shows that, for all misery measures other than suicide rates, the regressions predict accountants will have higher misery values than they do, with errors falling between the $16^{\text {th }}$ and $37^{\text {th }}$ percentiles among occupations. Accountants have far higher suicide rates than the model predicts, with errors falling in the $85^{\text {th }}$ (Panel A) and $83^{\text {rd }}$ (Panel B) percentiles. Other occupations with large errors in Panel A include "account \& bill collectors," who have far more job dissatisfaction and 
unhappiness than predicted, and "molding machine setters," who have far lower rates of job dissatisfaction, unhappiness, and mental health bad than predicted. Occupations with large errors in Panel B include "lawyers", who have far higher rates of job dissatisfaction and unhappiness than predicted, and "artists and related workers," who have far higher rates of unhappiness, mental health bad, and suicide than predicted.

To summarize this subsection, the descriptive results show that accounting has a number of unusual characteristics that are consistent with stereotypes of accounting work. With the exception of suicide rates, accountants again have low values for misery in an absolute sense and relative to the predictions of our models. Because of the messiness of the attribution of suicide rates to occupations, the suicide regressions have an ambiguous interpretation. It is not clear whether we are modelling occupational suicide rates or whether we are modeling the ease with which we can match occupation titles in the RAD suicide database with SOC job titles.

\section{Model 3}

Table 7 shows descriptive statistics for our model 3 variables, which come from Add health. Panel A shows data for all respondents who report that they work at least 10 hours a week and Panel B for those working at least 30 hours a week and holding at least a bachelor's degree. Accountants in Add health have values for our misery measures that are not statistically significantly different from others except for suicidal thoughts, which is significantly lower among accountants. We have relatively less statistical power in our Add health analyses of accountants because we have relatively few accounting observations (39 working $10+$ hours a week and 28 working $30+$ hours and having a college degree). In Panels A and B, accountants are less likely to report working long or irregular hours, using illegal drugs, and being sexually abused as children and are less likely to have extroverted personalities. They are more likely to 
have conscientious personalities. Relative to other college-educated workers, accountants are less likely to have many close friends and to use marijuana, but are more likely to have felt during adolescence that their parents cared about them. Several of these descriptive findings match stereotypes about accountants. Add health accountants are introverted, conscientious, and risk averse (drug use is more common among risk seekers (Blondel et al. 2007)).

Table 8 shows results for regressions modelling misery in Add health. None of the coefficients on accountants is statistically significant. Similar to the model 1 results, prestige is consistently significantly negatively associated with misery. The coefficients in the job dissatisfaction and suicidal thoughts columns are interpretable as changes in probabilities because these dependent variables are dichotomous. To illustrate their interpretation, the -0.023 coefficient on prestige in column one of Panel A signifies that, for each step up the "prestige ladder" a respondent takes, the probability that they will be dissatisfied with their job falls by 2.3\%. Given a base rate of job dissatisfaction in the column 1 sample of $7 \%$, this is a large effect. Coefficients in the depression and stress scale columns are interpretable as changes in these two psychometric scales, which range from 0 to 28 and 0 to 16 respectively. The column 5 coefficient on prestige of -0.388 signifies that each step up the "prestige ladder" is associated with a stress scale score that is lower by -0.388 , which represents an $8 \%$ change from the sample mean of 4.69. Table 8 further shows that having a neurotic personality or having been depressed in adolescence are positively associated with misery proxies across many of our models while having a conscientious or extraverted personality is negatively associated with misery. For each misery measure, we estimate models that do and do not include occupation fixed effects and 
again find that including occupation fixed effects rarely materially changes the results, consistent with the same covariates explaining misery between and within occupations. ${ }^{20}$

Together, our model 1,2, and 3 results suggest that accounting work has a number of characteristics associated with misery in non-accounting settings (model 1), but we find that accountants are not particularly miserable whether we compare misery in accounting against other occupations considering no controls or after considering a wide array of job characteristic, demographic, and psychosocial controls. We further find that accountants have a number of psychosocial traits that are negatively associated with misery and personalities that may be good matches for accounting work. The only exception to our finding of low misery in accounting comes from our suicide rate tests, which find that suicide rates in accounting are relatively high. Unfortunately, because of the limitations of our suicide rate data, we are not certain whether this result is reliable.

\section{CONCLUSIONS}

There is a paradox in prior literature on misery in accounting. On one hand, accounting is widely regarded as a miserable job by non-accountants, it has a number of characteristics associated with workplace misery in non-accounting settings, audit firms are known to have high turnover, auditors experience extreme burnout around busy season, and some commentary in the accounting literature argues that accounting is facing recruiting problems that could cripple it.

On the other hand, the accounting literature on burnout shows that accountants do not have especially high rates of burnout, except for auditors during busy season, and accountants

\footnotetext{
${ }^{20}$ Job dissatisfaction and suicidal thoughts are dichotomous dependent variables. We re-estimate our model 3 regressions explaining these two dependent variables using logit and find a pattern of results that is very similar to those presented.
} 
studying accounting stereotypes frequently argue or take for granted that accounting work is better than the stereotypes suggest.

In this study, we find that accounting stereotypes get a lot right. Accounting work is, in fact, more sedentary, repetitive, and rules-focused, and permits workers less room to make decisions or be creative than other jobs. All of these work characteristics have been shown to predict workplace misery in non-accounting settings, and we show that many of them predict misery in our settings as well. However, our evidence suggests that accountants are not particularly miserable, and offers a potential explanation: accounting is not a miserable job because people who become accountants are suited to accounting work. This interpretation of our results offers a different take on the costs and benefits of accounting stereotypes. Prior research on accounting stereotypes typically argues that they are costly because they influence the process by which people select into accounting careers, reducing their numbers and narrowing their characteristics. However, given evidence that workplace misery is very costly to workers, employers, and society, evaluations of accounting stereotypes and their influence on career selection are incomplete if they ignore their potential to improve matches between person and career. 


\section{References}

Albrecht, W.S. and R. J. Sack. 2000. Accounting Education: Charting the Course through a Perilous Future (Accounting Education Series). Sarasota, FL: American Accounting Association.

Allen, C. 2004. Business Students' Perception of the image of accounting. Managerial Auditing Journal 19 (2): 235-258.

Angrist, J. D., and J. S. Pischke. 2009. Mostly Harmless Econometrics: An Empiricist's Companion. Princeton, NJ: Princeton University Press.

Baldvinsdottir. G., J. Burns, H. Nørreklit, and R.W. Scapens. 2009. The image of accountants: from bean counters to extreme accountants. Accounting, Auditing and Accountability Journal 22 (6): 858-882.

Beard, V. 1994. Popular culture and professional identity: Accountants in the movies. Accounting, Organizations and Society 19 (3): 303-318.

Belski, W. H., K. A. Richmond, and J.A. Brozovsky. 2003. "A few bad apples in the bunch?”: A post-Enron examination of the business student's perception of the prestige of the accounting profession. Unpublished Working Paper.

Blondel, S., Y. Loheac, and S. Rinaudo. 2007. Rationality and drug use: An experimental approach. Journal of Health Economics 26 (3): 643-658.

Bougen, P. D. 1994. Joking apart: The serious side to the accountant stereotype. Accounting, Organizations and Society 19 (3): 319-335.

Brenninkmeyer, V., N. W. Van Yperen, and B. P. Buunk. 2001. Burnout and depression are not identical twins: is decline of superiority a distinguishing feature? Personality and Individual Differences 30 (5): 873-880.

Briggs, S., S. Copeland, and D. Haynes. 2007. Accountants for the $21^{\text {st }}$ Century: where are you? A five-year study of accounting students' personality preferences. Critical Perspectives on Accounting 18: 511-537.

Briner, R. B., C. Harris, and K. Daniels. 2004. How do stress and coping work? Toward a fundamental theoretical reappraisal. British Journal of Guidance and Counselling 32 (2): 223-234.

Caplan, R. D. 1987. Person-environment fit theory and organizations: Commensurate dimensions, time perspectives, and mechanisms. Journal of Vocational Behavior 31 (3): 248-267.

Chapman, G., E. Idle, T. Gilliam, T. Jones, J. Cleese, and M. Palin. 1989. The Complete Monty Python's Flying Circus: All the Words (Volume 1). New York: Pantheon Books.

Chen. C.C., K. T. Jones, A. N. Scarlata, and D. N. Stone. 2012. Does the Holland model of occupational choice (HMOC) perpetuate the beancounter-bookkeeper (BB) stereotype of accountants? Critical Perspectives on Accounting 23 (4-5): 370-389. 
Cohen, S., T. Kamarck, and R. Mermelstein. 1983. A global measure of perceived stress. Journal of Health and Social Behavior 24 (4): 385-396.

Cooper, C. L., P. J. Dewe, and M. P. O’Driscoll. 2001. Organizational Stress: A Review and Critique of Theory, Research, and Applications. Thousand Oaks, CA: Sage Publications, Inc.

Cordes, C. L., and T.W. Dougherty. 1993. A Review and an integration of research on job burnout. The Academy of Management Review 18 (4): 621-656.

Cory, S. N. 1992. Quality and quantity of accounting students and the stereotypical accountant: Is there a relationship? Journal of Accounting Education 10 (1): 1-24.

Cox, T., A. Griffiths, and E. Rial-Gonzalez. 2000. Research on Work-Related Stress. European Agency for Safety and Health at Work. Office for Official Publications of the European Communities, Luxembourg.

CPA Journal Online. 2018. The state of the profession: Analyzing the results of the 2018 practice management survey. The CPA Journal Online (December).

DeAngelis, T. 2011. Psychologist suicide. Monitor on Psychology-American Psychological Association 42 (10): 19.

DeCoster, D. T., and J. G. Rhode. 1971. The Accountant's stereotype: Real or imagined, deserved or unwarranted. The Accounting Review 46 (4): 651-664.

Dyrbye, L. N., M. R. Thomas, F. S. Massie, D. V. Power, A. Eacker, W. Harper, S. Durning, C. Moutier, D.W. Szydlo, P. J. Novotny, J. A. Sloan, and T. D. Shanafelt. 2008. Burnout and suicidal ideation among U.S. medical students. Annals of Internal Medicine 149 (5): 334-341.

Flood, S., M. King, R. Rodgers, S. Ruggles, and J. R. Warren. 2018. Integrated Public Use Microdata Series, Current Population Survey: Version 6.0 [dataset]. Minneapolis, MN: IPUMS. https://doi.org/10.18128/D030.V6.0.

Fogarty, T J., J. Singh, G. K. Roads, and R. K. Moore. 2000. Antecedents and consequences of burnout in accounting: Beyond the role stress model. Behavioral Research in Accounting 12: 31-67.

Friedman, A. L., and S. R. Lyne. 2001. The Beancounter Stereotype: Towards a general model of stereotype generation. Critical Perspectives on Accounting 12 (4): 423-451.

Freudenberger, H. J. 1974. Staff burn-out. Journal of Social Issues 30 (1): 159-165.

Freudenberger, H. J. 1975. The staff burn-out syndrome in alternative institutions. Psychotherapy: Theory, Research and Practice 12 (1): 73-82.

Girgus, J. S., and K. Yang. 2015. Gender and depression. Current Opinion in Psychology 4: 5360.

Goh, J., J. Pfeffer, and S. A. Zenios. 2015. The relationship between workplace stressors and mortality and health costs in the United States. Management Science 62 (2): 1-21. 
Grav, S., O. Hellzen, U. Romild, and E. Stordal. 2011. Association between social support and depression in the general population: The HUNT study, a cross-sectional survey. Journal of Clinical Nursing 21 (1-2): 111-120.

Haring-Hidore, M., W. A. Stock, M. A. Okun, and R. A. Witter. 1985. Marital status and subjective well-being: A research synthesis. Journal of Marriage and Family 47 (4): 947953.

Harris, K. M. 2009. The National Longitudinal Study of Adolescent Health (Add Health), Waves I \& II, 1994-1996; Wave III, 2001-2002; Wave IV, 2007-2009 [machine-readable dataset]. Chapel Hill, NC: Carolina Population Center, University of North Carolina at Chapel Hill.

Haslam, S. A., J. C. turner, P. J. Oakes, K. J. Reynolds, R. A. Eggins, M. Nolan, and J. Tweedie. 1998. When do stereotypes become really consensual? Investigating the group-based dynamics of the consensualization process. European Journal of Social Psychology 28 (5): 755-776.

Hassard, J., K. R. H. Teoh, G. Visockaite, P. Dewe, and T. Cox. 2017. The cost of work-related stress: a systematic review. Journal of Occupational Health Psychology 23 (1): 1-17.

Hofferth, S. L., S. M. Flood, and M. Sobek. American Time Use Survey Data Extract Builder [dataset]. College Park, MD: University of Maryland and Minneapolic, MN: IPUMS. https://doi.org/10.18128/D060.V2.7.

Jeacle, I. 2008. Beyond the boring grey: The construction of the colourful accountant. Critical Perspectives on Accounting 19 (8): 1296-1320.

Johnson, S., C. Cooper, S. Cartwright, I. Donald, P. Taylor, C. Millet. 2005. The experience of work-related stress across occupations. Journal of Managerial Psychology 20 (2): 178187.

Jones, A., C. S. Norman, and B. Wier. 2010. Healthy lifestyle as a coping mechanism for role stress in public accounting. Behavioral Research in Accounting 22 (1): 21-41.

Kalbers, L. P., and T. J. Fogarty. 2005. Antecedents to internal auditor burnout. Journal of Managerial Issues 17 (1): 101-118

Karam, F., A. Berard, O. Sheehy, M. C. Huneau, G. Briggs, C. Chambers, A. Einarson, D. Johnson, K. Kao, G. Koren, B. Martin, J. E. Polifka, S. H. Riordan, M. Roth, S. V. Lavigne, L. Wolfe, OTIS Research Committee. 2012. Reliability and validity of the 4item perceived stress scale among pregnant women: Results from the OTIS antidepressants study. Research in Nursing \& Health 35 (4): 363-375.

Karasek, R. A. 1979. Job demands, job decision latitude, and mental strain: Implications for job redesign. Administrative Science Quarterly 24 (2): 285-308.

Khaneman, D., and A. Deaton. 2010. High income improves evaluation of life but not emotional well-being. PNAS 107 (38): 16489-16493.

Kivimäki, M., M. Jokela, S. T. Nyberg, A. Singh-Manoux, E. I. Fransson, L. Alfredsson, J. B. Bjorner, M. Borritz, H. Burr, A. Casini, E. Clays, D. D. Bacquer, N. Dragano, R. Erbel, 
G. A. Geuskens, M. Hamer, W. E. Hooftman, I. L. Houtman, K. Jöckel, F. Kittel, A. Knutsson, M. Koskenvuo, T. Lunau, I. E. H. Madsen, M. L. Nielsen, M. Nordin, T. Oksanen, J. H. Pejtersen, J. Pentti, R. Rugulies, P. Salo, M. J. Shipley, J. Siegrist, A. Steptoe, S. B. Suominen, T. Theorell, J. Vahtera, P. J. M. Westerholm, H. Westerlund, D. O’Reilly, M. Kumari, G. D. Batty, J. E. Ferrie, M. Virtanen. 2015. Long working hours and risk of coronary heart disease and stroke: a systematic review and meta-analysis of published and unpublished data for 603,838 individuals. The Lancet 386 (10005): 17391746.

Leiby, J. and P. E. Madsen. 2017. Margin of safety: Life history strategies and the effects of socioeconomic status on self-selection into accounting. Accounting, Organizations and Society 60 (July): 21-36.

Leka, S., and A. Jain. 2010. Health Impact of Psychosocial Hazards at Work: An Overview. Geneva, Switzerland.: WHO Press, World Health Organization.

Lucas. R. E. 2005. Time does not heal all wounds: A longitudinal study of reaction and adaptation to divorce. Psychological Science 16 (12): 945-950.

Madsen, P. E. 2015. Has the quality of accounting education declined? The Accounting Review 90 (3): 1115-1147.

Mark, G. M. 2008. The Relationship between Workplace Stress, and Job Characteristics, Individual Differences, and Mental Health (Doctoral dissertation). Retrieved from ProQuest LLC. UMI Number: U585119.

Mark, G. M. and A. P. Smith. 2008. Stress Models: A Review and Suggested New Direction. In Occupational Health Psychology: European perspectives on research, education and practice 3, edited by J. Houdmont and S. Leka: 111-144.

Maslach, C. and S. E. Jackson. 1981. The measurement of experienced burnout. Journal of Occupational Behaviour 2 (2): 99-113.

McClean, L. H. and R. W. Clouse. 1991. Stress and Burnout: An Organizational Synthesis. Washington, DC: Office of Educational Research and Improvement, U.S. Department of Education.

McGarty, C., V. Y. Yzerbyt, and R. Spears. 2002. Stereotypes as Explanations: The Formation of Meaningful Beliefs about Social Groups. Cambridge U.K.: Cambridge University Press.

Melamed, S., I. Ben-Avi, J. Luz, and M. S. Green. 1995. Repetitive work, work underload and coronary heart disease risk factors among blue-collar workers - the Cordis Study. Journal of Psychosomatic Research 39 (1): 19-29.

Nusca, A. 2018. A burnout culture led to record attrition at PWC. So it Changed its Approach. Fortune (March 26).

Oshio, T., M. Umeda, and N. Kawakami. 2013. Childhood adversity and adulthood subjective well-being: Evidence from Japan. Journal of Happiness Study 14 (3): 843-860. 
Parkes, K. R. 1994. Personality and coping as moderators of work stress processes: Models, methods and measures. Work and Stress 8 (2): 110-129.

Prüss-Üstün, A. and C.F. Corvalán. 2006. Preventing disease through healthy environments: towards an estimate of the environmental burden of disease. Geneva, Switzerland.: WHO Press, World Health Organization.

Purtill, C. 2018. PWC's millennial employees led a rebellion-and their demands are being met. Quartz at Work (March 20).

Radloff , L. S. 1977. The CES-D scale: A self-reported depression scale for research in the general population. Applied Psychological Measurement 1 (3): 385-401.

Richardson, P., S. Dellaportas, L. Perera, and B. Richardson. 2015. Towards a conceptual framework on the categorization of stereotypical perceptions in accounting. Journal of Accounting Literature 35: 28-46.

Rizzo, J. R., R. J. House, and S. I. Lirtzman. 1970. Role conflict and ambiguity in complex organizations. Administrative Science Quarterly 15 (2): 150-163.

Shirom, A. 2003. Job-related burnout: A review. Handbook of Occupational Health Psychology. 245-264.

Smith, M., and S. Briggs. 1999. From bean-counter to action hero: Changing the image of the Accountant. Management Accounting (British) 77 (1): 28-31.

Smith, D. and K. Jacobs. 2011. "Breaking up the sky": The characterization of accounting and accountants in popular music. Accounting, Auditing \& Accountability Journal 24 (7): 904-931.

Smith, T. W., M. Davern, J. Freese, and M. Hout. 2018. General Social Surveys, 1972-2016 [machine-readable data file]. Sponsored by National Science Foundation. NORC ed. Chicago: NORC at the University of Chiago [producer]; Storrs, CT: The Roper Center for Public Opinion Research, University of Connecticut [distributor].

Sottile, L. 2016. The AEC Industry's Deadly Problem. Architect (August 31).

Sparks, K. and C. L. Cooper. 1999. Occupational differences in the work-strain relationship: Towards the use of situation-specific models. Journal of Occupational and Organizational Psychology 72 (2): 219-229

Stanley, I. H., M. A. Hom, and T. E. Joiner. 2016. A systematic review of suicidal thoughts and behaviors among police officers, firefighters, EMTs, and paramedics. Clinical Psychology Review 44: 25-44.

Sutin, A. R, A. Terracciano, Y. Milaneschi, Y. An, L. Ferrucci, and A. B. Zonderman. 2013. Cohort effect on well-being: The legacy of economic hard times. Psychological Science 24 (3): $379-385$

Sweeney, J. T., and S. L. Summers. 2002. The effect of the busy season workload on public accountants' job burnout. Behavioral Research in Accounting 14 (1): 223-245 
Swendsen, J. D., and K. R. Merikangas. 2000. The comorbidity of depression and substance use disorders. Clinical Psychology Review 20 (2): 173-189

Toker, S., S. Melamed, S. Berliner, D. Zeltser, and I. Shapira. 2012. Burnout and risk of coronary heart disease: A prospective study of 8,838 employees. Psychosomatic Medicine 74 (8): 840-847.

Tomasi, S. E., E. D. Fechter-Leggett, N. T. Edwards, A. D. Reddish, A. E. Crosby, and R. J. Nett. 2019. Suicide among veterinarians in the United States from 1979 through 2015. Journal of the American Veterinary Medical Association 254 (1): 104-112.

Tribe, M. 2018. As attorney suicides mount, a survivor speaks out. The American Lawyer (November 12).

Valentine, R. J. 2017. The hidden cost of medicine. Journal of the American College of Surgeons 225 (1): 1-8.

van Veldhoven, M., T. W. Taris, J. de Jonge, and S. Broersen. 2005. The relationship between work characteristics and employee health and well-being: How much complexity do we really need? International Journal of Stress Management 12 (1): 3-28

Warren, S., and L. Parker. 2009. Bean counters or bright young things? Towards the visual study of identity construction among professional accountants. Qualitative Research in Accounting and Management 6 (4): 205-223.

West, C. P., L. N. Dyrbye, P. J. Erwin, and T. D. Shanafelt. 2016. Interventions to prevent and reduce physician burnout: A systematic review and meta-analysis. The Lancet 388 (10057): 2272-2281.

Wickrama, K. A. S., S. Noh, and G. H. Elder. 2009. An investigation of family SES-based inequalities in depressive symptoms from early adolescence to emerging adulthood. Advances in Life Course Research 14 (3): 147-161

Witter, R. A., M. A. Okun, W. A. Stock, and M. J. Haring. 1984. Education and subjective wellbeing: a meta-analysis. Educational Evaluation and Policy Analysis 6 (2): 165-173

World Health Organization (WHO). 2004. The Global Burden of Disease: 2004 Update. Geneva, Switzerland: WHO Press, World Health Organization. 
Appendix

Detailed Variable Definitions

In this appendix, we describe variable sources and definitions. Our variables come from 7 sources, which are:

1. General Social Survey (http://gss.norc.org/get-the-data/stata) $\rightarrow$ GSS 1972-2016 CrossSectional Cumulative Data (Release 4, August 16, 2018).

2. O*NET 20.1 October 2015 Version (https://www.onetcenter.org/db_releases.html)

3. IPUMS-CPS (https://cps.ipums.org/cps/index.shtml)

4. IPUMS-ATUS-X (https://www.ipums.org/timeuse.shtml)

5. Occupational Employment Statistics (OES) (https://www.bls.gov/oes/tables.htm) $\rightarrow$ State-level Statistics.

6. National Longitudinal Study of Adolescent Health (Add health) (https://www.icpsr.umich.edu/icpsrweb/DSDR/studies/21600/datadocumentation) $\rightarrow$ inhome questionnaires for wave 1 (DS1) and wave 4 (DS22).

7. National Violent Death Reporting System Restricted Access Database (CDC RAD database) (not publicly available) (https://www.cdc.gov/violenceprevention/datasources/nvdrs/index.html).

In the remainder of this Appendix, we list tables for models 1, 2, and 3 showing variable labels and sources in parentheses in column 1, variable definitions in column 2, and notes describing how to locate them in the source database in column 3.

Some GSS variables are not available in every GSS data collection year. In these cases, we list the years during which the variable was available.

When calculating some model 2 occupation-level variables, we use values only from the subset of states reporting data to the NVDRS RAD suicide database. When this is the case, we note it in the "definition column". NVDRS RAD states are: Alaska, Arizona, Colorado, Connecticut, Georgia, Hawaii, Illinois, Indiana, Iowa, Kansas, Kentucky, Maine, Maryland, Massachusetts, Michigan, Minnesota, New Hampshire, New Jersey, New Mexico, New York, North Carolina, Ohio, Oklahoma, Oregon, Pennsylvania, Rhode Island, South Carolina, Utah, Vermont, Virginia, Washington, and Wisconsin. 
Model 1

\begin{tabular}{|c|c|c|}
\hline Variable & Definition & Notes \\
\hline $\begin{array}{l}\text { Job dissatisfaction } \\
(\text { GSS })\end{array}$ & $\begin{array}{l}\text { A dummy variable equal to } 1 \text { for respondents who are "a little } \\
\text { dissatisfied" or "very dissatisfied" with their job and zero otherwise. }\end{array}$ & GSS: Satjob \\
\hline $\begin{array}{l}\text { Unhappiness } \\
(\text { GSS })\end{array}$ & $\begin{array}{l}\text { A dummy variable equal to } 1 \text { for respondents who are "not too } \\
\text { happy" and zero otherwise. }\end{array}$ & GSS: Happy \\
\hline $\begin{array}{l}\text { Accounting } \\
(\text { GSS })\end{array}$ & $\begin{array}{l}\text { A dummy variable equal to } 1 \text { for people who say their occupation is } \\
\text { "accountants and auditors" and zero otherwise }(\operatorname{occ} 10=800)\end{array}$ & GSS: Occ10 \\
\hline $\begin{array}{c}\text { Income } \\
\text { (GSS) }\end{array}$ & Respondent's income in constant 1986 dollars. & $\begin{array}{l}\text { GSS: Realrinc } \\
\text { Available 1974-2016. }\end{array}$ \\
\hline $\begin{array}{l}\text { Prestige } \\
(G S S)\end{array}$ & $\begin{array}{l}\text { The prestige of occupations in GSS were evaluated by random } \\
\text { samples of Americans in 1963-1965, 1989, and 2012. The evaluation } \\
\text { involves placing cards showing occupation titles on a } 9 \text { rung } \\
\text { "ladder", with rung } 1 \text { labelled "bottom", rung } 5 \text { labelled "middle", } \\
\text { and rung } 9 \text { labelled "top" according to the "social standing" of the } \\
\text { occupation. Occupation scores are calculated by averaging } \\
\text { respondents' rung rankings, and transforming the variable to be on a } \\
0 \text { to } 100 \text { scale. }\end{array}$ & GSS: Prestg10 \\
\hline $\begin{array}{l}\text { Hours worked } \\
\quad(\text { GSS })\end{array}$ & The number of hours the respondent worked last week. & $\begin{array}{l}\text { GSS: Hrs1 } \\
\text { Available 1973-2016. }\end{array}$ \\
\hline $\begin{array}{l}\text { Long hours } \\
\text { (GSS) }\end{array}$ & $\begin{array}{l}\text { A dummy variable equal to } 1 \text { for respondents with hours worked } \\
\text { values greater than } 55 \text { hours and zero otherwise }(\mathrm{hrs} 1>55) \text {. }\end{array}$ & $\begin{array}{l}\text { GSS: Hrs1 } \\
\text { Available 1973-2016. }\end{array}$ \\
\hline $\begin{array}{l}\text { High school graduate } \\
\text { (GSS) }\end{array}$ & $\begin{array}{l}\text { An indicator variable equal to } 1 \text { if the respondent's highest degree is } \\
\text { a high school diploma or a junior college degree and zero otherwise } \\
\text { (degree }=1 \text { or } 2 \text { ). }\end{array}$ & GSS: Degree \\
\hline $\begin{array}{l}\text { Bachelor's degree } \\
\text { (GSS) }\end{array}$ & $\begin{array}{l}\text { An indicator variable equal to } 1 \text { if the respondent's highest degree is } \\
\text { a bachelor's degree and zero otherwise (degree }=3 \text { ). }\end{array}$ & GSS: Degree \\
\hline $\begin{array}{c}\text { Master's degree } \\
(G S S)\end{array}$ & $\begin{array}{l}\text { An indicator variable equal to } 1 \text { if the respondent's highest degree is } \\
\text { a "graduate" degree and zero otherwise }(\text { degree }=4) \text {. }\end{array}$ & GSS: Degree \\
\hline $\begin{array}{c}\text { Female } \\
(G S S)\end{array}$ & $\begin{array}{l}\text { An indicator variable equal to } 1 \text { if the respondent's sex is female and } \\
\text { zero otherwise }(\operatorname{sex}=2) \text {. }\end{array}$ & GSS: Sex \\
\hline $\begin{array}{l}\text { Age } \\
(G S S)\end{array}$ & Respondent's age in years. & GSS: Age \\
\hline $\begin{array}{l}\text { Married } \\
(\text { GSS })\end{array}$ & $\begin{array}{l}\text { An indicator variable equal to } 1 \text { for respondents who are married and } \\
\text { zero otherwise }(\text { marital }=1) \text {. }\end{array}$ & GSS: Marital \\
\hline $\begin{array}{l}\text { Ever divorced } \\
\quad(G S S)\end{array}$ & $\begin{array}{l}\text { An indicator variable equal to } 1 \text { for respondents who have ever been } \\
\text { divorced or legally separated (divorce }=1 \text { ). }\end{array}$ & GSS: Divorce \\
\hline $\begin{array}{l}\text { Childhood income } \\
\text { low } \\
(\text { GSS })\end{array}$ & $\begin{array}{l}\text { An indicator variable equal to } 1 \text { for respondents who estimated that } \\
\text { their family income when they were } 16 \text { years old was "below } \\
\text { average" or "far below average" (income } 16=1 \text { or } 2 \text { ). }\end{array}$ & $\begin{array}{l}\text { GSS: Incom16 } \\
\text { Available } 1972-1994 \text { and } \\
\text { 2002-2016. }\end{array}$ \\
\hline $\begin{array}{l}\text { Childhood income } \\
\text { high } \\
\text { (GSS) }\end{array}$ & $\begin{array}{l}\text { An indicator variable equal to } 1 \text { for respondents who estimated that } \\
\text { their family income when they were } 16 \text { years old was "above } \\
\text { average" or "far above average" (income } 16=4 \text { or } 5 \text { ). }\end{array}$ & $\begin{array}{l}\text { GSS: Incom16 } \\
\text { Available 1972-1994 and } \\
\text { 2002-2016. }\end{array}$ \\
\hline $\begin{array}{l}\text { Close friends } \\
\qquad(\text { GSS })\end{array}$ & $\begin{array}{l}\text { An indicator variable equal to } 1 \text { for respondents who report spending } \\
\text { "a social evening with friends who live outside the neighborhood" } \\
\text { more frequently than once a month (socfrend }=1,2 \text {, or } 3 \text { ). }\end{array}$ & $\begin{array}{l}\text { GSS: Socfrend } \\
\text { Available } 1974-75,77-78, \\
82-83,85-86 \text {, and } 88-2016 .\end{array}$ \\
\hline $\begin{array}{l}\text { Close family } \\
\qquad(G S S)\end{array}$ & $\begin{array}{l}\text { An indicator variable equal to } 1 \text { for respondents who report spending } \\
\text { "a social evening with relatives" more frequently than once a month } \\
\text { (socrel }=1,2 \text {, or } 3 \text { ) }\end{array}$ & $\begin{array}{l}\text { GSS: Socrel } \\
\text { Available 1974-75, 77-78, } \\
\text { 82-83, 85-86, and 88-2016. }\end{array}$ \\
\hline $\begin{array}{l}\text { Weekly church } \\
\text { (GSS) }\end{array}$ & $\begin{array}{l}\text { An indicator variable equal to } 1 \text { for respondents who reported } \\
\text { attending church "every week" or more frequently (attend = } 7 \text { or } 8 \text { ) }\end{array}$ & GSS: Attend \\
\hline
\end{tabular}


Model 2

\begin{tabular}{|c|c|c|}
\hline Variable & Definition & Notes \\
\hline $\begin{array}{c}\text { Job } \\
\text { dissatisfaction } \\
(\text { GSS })\end{array}$ & $\begin{array}{l}\text { An occupation average of an individual-level dummy variable equal to } 1 \text { for } \\
\text { respondents who are "a little dissatisfied" or "very dissatisfied" with their job } \\
\text { and zero otherwise. }\end{array}$ & GSS: Satjob \\
\hline $\begin{array}{l}\text { Unhappiness } \\
\text { (GSS) }\end{array}$ & $\begin{array}{l}\text { An occupation average of an individual-level dummy variable equal to } 1 \text { for } \\
\text { respondents who are "not too happy" and zero otherwise. }\end{array}$ & GSS: Happy \\
\hline $\begin{array}{l}\text { Mental health } \\
\text { bad } \\
\text { (GSS) }\end{array}$ & $\begin{array}{l}\text { An occupation average of an individual-level measure of the number of days } \\
\text { during the last month that workers in occupation i report having mental health } \\
\text { that was "not good" for reasons including stress, depression, and problems } \\
\text { with emotions. }\end{array}$ & $\begin{array}{l}\text { GSS: Mnthlth } \\
\text { Available 2002-2006 and } \\
\text { 2010-2016. }\end{array}$ \\
\hline $\begin{array}{l}\text { Suicide rate } \\
(R A D \text { and } O E S)\end{array}$ & $\begin{array}{l}\text { An occupation level estimate of the suicide rate per } 1,000 \text { workers. We } \\
\text { estimate the number of suicides by occupation using RAD data over the years } \\
2003-2015 \text {, dividing this value by the total number of people working in } \\
\text { NVDRS states in the occupation over the same years, and multiplying by } \\
1,000 \text {. }\end{array}$ & $\begin{array}{l}\text { RAD: Suicides } \\
\text { OES: Tot_emp }\end{array}$ \\
\hline $\begin{array}{c}\text { Status } \\
\text { (factor analysis) }\end{array}$ & A factor variable measuring the status of the occupation. & $\begin{array}{l}\text { All independent variables } \\
\text { from model } 2 .\end{array}$ \\
\hline $\begin{array}{c}\text { Blue collar } \\
\text { (factor analysis) }\end{array}$ & $\begin{array}{l}\text { A factor variable measuring the extent to which the occupation is a blue- } \\
\text { collar occupation. }\end{array}$ & $\begin{array}{l}\text { All independent variables } \\
\text { from model } 2 \text {. }\end{array}$ \\
\hline $\begin{array}{c}\text { Repetitive } \\
\text { (factor analysis) }\end{array}$ & $\begin{array}{l}\text { A factor variable measuring the extent to which the occupation does } \\
\text { repetitive work. }\end{array}$ & $\begin{array}{l}\text { All independent variables } \\
\text { from model } 2 \text {. }\end{array}$ \\
\hline $\begin{array}{c}\text { Security } \\
\text { (factor analysis) }\end{array}$ & A factor variable measuring the job security of the occupation. & $\begin{array}{l}\text { All independent variables } \\
\text { from model } 2 .\end{array}$ \\
\hline $\begin{array}{c}\text { Income } \\
(O E S)\end{array}$ & $\begin{array}{l}\text { An occupation average of the state-level pay received by workers in the } \\
\text { occupation during the years } 2003 \text { to } 2015 \text {. Calculated using NVDRS states } \\
\text { only. }\end{array}$ & OES: A_mean \\
\hline $\begin{array}{l}\text { Proportion } 40+ \\
\text { hours }\end{array}$ & $\begin{array}{l}\text { An indicator variable equal to } 1 \text { for an occupation if } 90 \% \text { or more } \\
\text { respondents in an occupation report that they work more than } 40 \text { hours in a } \\
\text { typical workweek. }\end{array}$ & $\begin{array}{l}\text { O*NET context file: } \\
\text { Duration of typical } \\
\text { work week }\end{array}$ \\
\hline $\begin{array}{l}\text { Competitive } \\
\text { pressure }\end{array}$ & $\begin{array}{l}\text { A measure of the extent to which workers report that their work requires them } \\
\text { to compete or be aware of competitive pressures. Weighted average of } \\
\text { individual-level responses on a 5-point scale. }\end{array}$ & $\begin{array}{l}\text { O*NET context file: } \\
\text { Level of competition }\end{array}$ \\
\hline Time pressure & $\begin{array}{l}\text { A measure of the extent to which workers report that their work requires them } \\
\text { to meet strict deadlines. Weighted average of individual-level responses on a } \\
\text { 5-point scale. }\end{array}$ & $\begin{array}{l}\text { O*NET context file: } \\
\text { Time pressure }\end{array}$ \\
\hline Time off easy & $\begin{array}{l}\text { An occupation average of a measure of the extent to which workers in } \\
\text { occupation i say that it is hard for them to take time off from work to take } \\
\text { care of "personal or family matters." The individual-level variable has a value } \\
\text { of } 2 \text { for respondents who say that the statement is "not at all hard" (famwkoff } \\
=1), 1 \text { for "not too hard" (jobsecok }=2 \text { ), and zero otherwise. }\end{array}$ & $\begin{array}{l}\text { GSS: famwkoff } \\
\text { Available } 2002,2006, \\
2010 \text { and } 2014 .\end{array}$ \\
\hline $\begin{array}{l}\text { Work related } \\
\quad \text { travel }\end{array}$ & $\begin{array}{l}\text { An occupation average of an individual-level measure of the number of hours } \\
\text { people spent on work related travel during a } 24 \text {-hour reference period. }\end{array}$ & $\begin{array}{l}\text { IPUMS-ATUS-X: } \\
\text { BLS_WORK_TRAVEL } \\
\text { (180501) }\end{array}$ \\
\hline Job security & $\begin{array}{l}\text { An occupation average of a measure of the extent to which workers agree that } \\
\text { their job security is good. The individual-level variable has a value of } 2 \text { for } \\
\text { respondents who say that the statement is "very true" (jobsecok=1), } 1 \text { for } \\
\text { "somewhat true" (jobsecok =2), and zero otherwise. }\end{array}$ & $\begin{array}{l}\text { GSS: jobsecok } \\
\text { Available } 2002,2006, \\
\text { and } 2010-2014 \text {. }\end{array}$ \\
\hline Promotions fair & $\begin{array}{l}\text { An occupation average of a measure of the extent to which workers agree that } \\
\text { "promotions are handled fairly" at work. The individual-level variable has a } \\
\text { value of } 2 \text { for respondents who respond that the statement is "very true" } \\
\text { (promotefr }=1), 1 \text { for "somewhat true" (promotefr }=2 \text { ), and zero otherwise. }\end{array}$ & $\begin{array}{l}\text { GSS promtefr } \\
\text { Available } 2002,2006, \\
\text { and } 2010-2014 \text {. }\end{array}$ \\
\hline Active learning & $\begin{array}{l}\text { A measure of the extent to which workers report that their work requires } \\
\text { active learning. Weighted average of individual-level responses on a 5-point } \\
\text { scale. }\end{array}$ & $\begin{array}{l}\text { O*NET skill file: Active } \\
\text { Learning }\end{array}$ \\
\hline $\begin{array}{l}\text { On the job } \\
\text { training }\end{array}$ & $\begin{array}{l}\text { A measure of the amount of training needed for occupation i as reported in } \\
\text { O*NET “job zones." Weighted average of individual-level responses on a 5- } \\
\text { point scale. }\end{array}$ & $\begin{array}{l}\text { O*NET education file: } \\
\text { Training: OJ }\end{array}$ \\
\hline
\end{tabular}




\begin{tabular}{|c|c|c|}
\hline $\begin{array}{l}\text { Free to make } \\
\text { decisions }\end{array}$ & $\begin{array}{l}\text { A measure of the extent to which workers are free to make decisions at work. } \\
\text { Weighted average of individual-level responses on a 5-point scale. }\end{array}$ & $\begin{array}{l}\text { O*NET context file: } \\
\text { Freedom to make } \\
\text { decisions }\end{array}$ \\
\hline Adaptability & $\begin{array}{l}\text { A measure of the extent to which workers report that their work requires them } \\
\text { to do different things each day. Weighted average of individual-level } \\
\text { responses on a 5-point scale across two O*NET variables. }\end{array}$ & $\begin{array}{l}\text { O*NET style file: } \\
\text { Adaptability/flexibility } \\
\text { O*NET ability file: Time } \\
\text { sharing }\end{array}$ \\
\hline Repeat tasks & $\begin{array}{l}\text { A measure of the extent to which the occupation requires its workers to repeat } \\
\text { the same tasks. Weighted average of individual-level responses on a 5-point } \\
\text { scale. }\end{array}$ & $\begin{array}{l}\mathrm{O} * \mathrm{NET} \text { context file: } \\
\text { Importance of } \\
\text { repeating same tasks }\end{array}$ \\
\hline Standards & $\begin{array}{l}\text { A measure of the extent to which the occupation requires its workers to } \\
\text { evaluate information to determine if it complies with laws, regulations, and } \\
\text { standards. Weighted average of individual-level responses on a 5-point scale. }\end{array}$ & $\begin{array}{l}\mathrm{O} * \mathrm{NET} \text { activities file: } \\
\text { Importance of } \\
\text { evaluating information } \\
\text { to determine } \\
\text { compliance with } \\
\text { standards }\end{array}$ \\
\hline $\begin{array}{l}\text { Creative } \\
\text { thinking }\end{array}$ & $\begin{array}{l}\text { A measure of the extent to which the occupation requires its workers to think } \\
\text { creatively. Weighted average of individual-level responses on a 5-point scale. }\end{array}$ & $\begin{array}{l}\text { O*NET activities file: } \\
\text { Importance of thinking } \\
\text { creatively }\end{array}$ \\
\hline Indoor & $\begin{array}{l}\text { A measure of the extent to which the occupation requires its workers to work } \\
\text { indoors. Weighted average of individual-level responses on a 5-point scale. }\end{array}$ & $\begin{array}{l}\text { O*NET context file: } \\
\text { Indoors, } \\
\text { environmentally } \\
\text { controlled }\end{array}$ \\
\hline Sitting & $\begin{array}{l}\text { A measure of the extent to which the occupation requires its workers to spend } \\
\text { time sitting. Weighted average of individual-level responses on a 5-point } \\
\text { scale. }\end{array}$ & $\begin{array}{l}\text { O*NET context file: } \\
\text { Spend time sitting }\end{array}$ \\
\hline $\begin{array}{l}\text { Awkward } \\
\text { positions }\end{array}$ & $\begin{array}{l}\text { A measure of the frequency with which the occupation requires its workers to } \\
\text { work in cramped spaces or get into awkward positions. Weighted average of } \\
\text { individual-level responses on a 5-point scale. }\end{array}$ & $\begin{array}{l}\text { O*NET context file: } \\
\text { Cramped work space, } \\
\text { awkward positions }\end{array}$ \\
\hline Physical activity & $\begin{array}{l}\text { A measure of the extent to which the occupation requires its workers to } \\
\text { perform physical activities that require "considerable use" of their arms, legs, } \\
\text { or whole body. Weighted average of individual-level responses on a 5-point } \\
\text { scale. }\end{array}$ & $\begin{array}{l}\text { O*NET activities file: } \\
\text { Performing general } \\
\text { physical activities }\end{array}$ \\
\hline $\begin{array}{l}\text { Education } \\
\text { requirement }\end{array}$ & $\begin{array}{l}\text { A measure of the level of education required to work in an occupation. } \\
\text { Weighted average of individual-level responses on a 5-point scale. }\end{array}$ & $\begin{array}{l}\text { O*NET education file: } \\
\text { Required level of } \\
\text { education }\end{array}$ \\
\hline Male & $\begin{array}{l}\text { The percentage of workers in the occupation that are male. Calculated using } \\
\text { NVDRS states only }(\operatorname{sex}=1) \text {. }\end{array}$ & CPS: Sex \\
\hline Divorced & $\begin{array}{l}\text { A measure of the percentage of workers in an occupation that are divorced } \\
(\text { marst }=4) \text {. Calculated using NVDRS states only. }\end{array}$ & CPS: Marst \\
\hline Age & $\begin{array}{l}\text { A measure of the average age of workers in an occupation. Calculated using } \\
\text { NVDRS states only. }\end{array}$ & CPS: Age \\
\hline Monthly church & $\begin{array}{l}\text { An occupation average of an individual-level dummy variable which is equal } \\
\text { to } 1 \text { for respondents who attend church at least monthly (attend }=4,5,6,7 \text {, or } \\
8 \text { ). }\end{array}$ & GSS: Attend \\
\hline Gun ownership & $\begin{array}{l}\text { An occupation average of an individual-level dummy variable which is equal } \\
\text { to } 1 \text { for respondents who report that they "have in your home any guns or } \\
\text { revolvers" and zero otherwise (owngun }=1 \text { ). }\end{array}$ & $\begin{array}{l}\text { GSS: Owngun } \\
\text { Available } 1973-74,76- \\
77,80-82,84-85 \text {, and } 87- \\
2016 .\end{array}$ \\
\hline
\end{tabular}


Model 3

\begin{tabular}{|c|c|c|}
\hline Variable & Definition & Notes \\
\hline $\begin{array}{c}\text { Job } \\
\text { dissatisfaction } \\
\end{array}$ & $\begin{array}{l}\text { A dummy variable equal to } 1 \text { for respondents who are "dissatisfied" or "extremely } \\
\text { dissatisfied" with their job and zero otherwise (H4LM26=4 or 5). }\end{array}$ & $\begin{array}{l}\text { Add health: } \\
\text { H4LM26 }\end{array}$ \\
\hline Depression & $\begin{array}{l}\text { A scale measure of depression adapted from the Center for Epidemiologic Studies } \\
\text { Depression Scale (CES-D). It is the sum of } 10 \text { questions, each with a response } \\
\text { coded to a number between } 0 \text { (less depression) and } 3 \text { (more depression). }\end{array}$ & $\begin{array}{l}\text { Add health: } \\
\text { H4MH18 through } \\
\text { H4MH27 }\end{array}$ \\
\hline Stress scale & $\begin{array}{l}\text { A scale measure of perceived stress from the Cohen Perceived Stress Scale. It is } \\
\text { the sum of } 4 \text { questions, each with a response coded to a number between } 0 \text { (less } \\
\text { stress) and } 4 \text { (more stress). }\end{array}$ & $\begin{array}{l}\text { Add health: H4MH3 } \\
\text { through H4MH6 }\end{array}$ \\
\hline $\begin{array}{l}\text { Suicidal } \\
\text { thoughts }\end{array}$ & $\begin{array}{l}\text { An indicator variable equal to } 1 \text { for respondents who report that, during the last } 12 \\
\text { months, they have "ever seriously thought about committing suicide" (H4SE1 = } \\
\text { 1). }\end{array}$ & Add health: H4SE1 \\
\hline Accountants & $\begin{array}{l}\text { An indicator variable equal to } 1 \text { for respondents whose occupation is "accountants } \\
\text { and auditors" and zero otherwise (H4LM18 = 13-2011). Add health uses the SOC } \\
\text { occupation classification system. }\end{array}$ & $\begin{array}{l}\text { Add health: } \\
\text { H4LM18 }\end{array}$ \\
\hline Income & $\begin{array}{l}\text { Respondents' personal, pre-tax income, which we adjust to be in tens of thousands } \\
\text { of } 2016 \text { dollars. }\end{array}$ & Add health: H4EC2 \\
\hline Prestige & $\begin{array}{l}\text { A scale representing "where you think you stand at this time in your life relative to } \\
\text { other people in the United States" on a ladder representing "people who have the } \\
\text { most money and education, and the most respected jobs" at the top (step 10) and } \\
\text { "people who have the least money and education, and the least respected jobs or } \\
\text { no job" at the bottom (step 1). }\end{array}$ & Add health: H4EC19 \\
\hline Hours worked & The number of hours the respondent usually works in a week. & $\begin{array}{l}\text { Add health: } \\
\text { H4LM19 }\end{array}$ \\
\hline Long hours & $\begin{array}{l}\text { An indicator variable equal to } 1 \text { for respondents who usually work more than } 55 \\
\text { hours a week and zero otherwise (H4LM19>55). }\end{array}$ & $\begin{array}{l}\text { Add health: } \\
\text { H4LM19 }\end{array}$ \\
\hline Irregular hours & $\begin{array}{l}\text { An indicator variable equal to } 1 \text { for respondents who report working rotating or } \\
\text { irregular shifts and zero otherwise (H4LM } 20=4 \text { or } 6 \text { ). }\end{array}$ & $\begin{array}{l}\text { Add health: } \\
\text { H4LM20 }\end{array}$ \\
\hline $\begin{array}{l}\text { Free to make } \\
\text { decisions }\end{array}$ & $\begin{array}{l}\text { An indicator variable equal to } 1 \text { for respondents who feel that they are free to make } \\
\text { important decisions about "what you do" and "how you do it" at work "most of the } \\
\text { time" or "all of the time" and zero otherwise (H4LM } 23=2 \text { or } 3 \text { ). }\end{array}$ & $\begin{array}{l}\text { Add health: } \\
\text { H4LM23 }\end{array}$ \\
\hline Work repetitive & $\begin{array}{l}\text { An indicator variable equal to } 1 \text { for respondents who feel that they "do the same } \\
\text { things repeatedly" at work "most of the time" or "all of the time" and zero } \\
\text { otherwise (H4LM } 24=2 \text { or } 3 \text { ). }\end{array}$ & $\begin{array}{l}\text { Add health: } \\
\text { H4LM24 }\end{array}$ \\
\hline $\begin{array}{l}\text { High school } \\
\text { graduate }\end{array}$ & $\begin{array}{l}\text { An indicator variable equal to } 1 \text { for respondents whose highest level of education } \\
\text { is "high school graduate," "some vocational/technical training after high school," } \\
\text { "completed vocational/technical training after high school," or "some college" and } \\
\text { zero otherwise (H4ED2 }=3,4,5 \text {, or } 6) \text {. }\end{array}$ & Add health: H4ED2 \\
\hline $\begin{array}{l}\text { Bachelor's } \\
\text { degree }\end{array}$ & $\begin{array}{l}\text { An indicator variable equal to } 1 \text { for respondents whose highest level of education } \\
\text { is "completed college (bachelor's degree)" or "some graduate school" and zero } \\
\text { otherwise (H4ED2 = } 7 \text { or } 8 \text { ). }\end{array}$ & Add health: H4ED2 \\
\hline $\begin{array}{l}\text { Master's } \\
\text { degree }\end{array}$ & $\begin{array}{l}\text { An indicator variable equal to } 1 \text { for respondents whose highest level of education } \\
\text { is "completed a master's degree," "some graduate training beyond a master's } \\
\text { degree," or "some post baccalaureate professional education" and zero otherwise } \\
\text { (H4ED2 }=9,10, \text { or } 12) \text {. }\end{array}$ & Add health: H4ED2 \\
\hline Doctorate & $\begin{array}{l}\text { An indicator variable equal to } 1 \text { for respondents whose highest level of education } \\
\text { is "completed a doctoral degree" and zero otherwise (H4ED2 = 11). }\end{array}$ & Add health: H4ED2 \\
\hline $\begin{array}{l}\text { Professional } \\
\text { degree }\end{array}$ & $\begin{array}{l}\text { An indicator variable equal to } 1 \text { for respondents whose highest level of education } \\
\text { is "completed post baccalaureate professional education (e.g., law school, med } \\
\text { school, nurse)" and zero otherwise (H4ED2 = 13). }\end{array}$ & Add health: H4ED2 \\
\hline Female & An indicator variable equal to 1 for women and zero otherwise (BIO_SEX $=2$ ). & $\begin{array}{l}\text { Add health: } \\
\text { BIO_SEX }\end{array}$ \\
\hline $\begin{array}{l}\text { Childhood } \\
\text { income }\end{array}$ & $\begin{array}{l}\text { A measure of respondents' families' incomes, taken during adolescence, which we } \\
\text { adjust to be in terms of tens of thousands of } 2016 \text { dollars. }\end{array}$ & Add health: PA55 \\
\hline $\begin{array}{c}\text { Family } \\
\text { interferes work }\end{array}$ & $\begin{array}{l}\text { An indicator variable equal to } 1 \text { for respondents who "strongly agree" or "agree" } \\
\text { with the statement "family responsibilities have interfered with my ability to } \\
\text { work" and zero otherwise (H4LM } 28=1 \text { or } 2 \text { ). }\end{array}$ & $\begin{array}{l}\text { Add health: } \\
\text { H4LM28 }\end{array}$ \\
\hline
\end{tabular}




\begin{tabular}{|c|c|c|}
\hline $\begin{array}{l}\text { Work interferes } \\
\quad \text { family }\end{array}$ & $\begin{array}{l}\text { An indicator variable equal to } 1 \text { for respondents who report that they have felt } \\
\text { "frequently" or "sometimes" that they spent less time with their family than they } \\
\text { wanted because of work responsibilities (H4LM30 = } 1 \text { or } 2 \text { ). }\end{array}$ & $\begin{array}{l}\text { Add health: } \\
\text { H4LM30 }\end{array}$ \\
\hline Daily prayer & $\begin{array}{l}\text { An indicator variable equal to } 1 \text { for people who pray privately at least daily and } \\
\text { zero otherwise (H4RE } 10=6 \text { or } 7) \text {. }\end{array}$ & Add health: H4RE10 \\
\hline Weekly church & $\begin{array}{l}\text { An indicator variable equal to } 1 \text { for people who attend church at least weekly and } \\
\text { zero otherwise (H4RE7 }=4 \text { or } 5 \text { ). }\end{array}$ & Add health: H4RE7 \\
\hline Close friends & $\begin{array}{l}\text { A measure of the number of close friends respondents have, meaning people you } \\
\text { "feel at ease with, can talk to about private matters, and can call for help." It is a } \\
\text { value from } 1 \text { to } 5 \text { with } 1 \text { representing "none" and } 5 \text { representing " } 10 \text { or more } \\
\text { friends." }\end{array}$ & Add health: H4WS4 \\
\hline $\begin{array}{l}\text { Excessive } \\
\text { drinking }\end{array}$ & $\begin{array}{l}\text { An indicator variable equal to } 1 \text { for respondents who report drinking behaviors that } \\
\text { the CDC defines as "excess drinking." Excess drinking is either "binge drinking," } \\
\text { which is defined as drinking } 4 \text { or more drinks (for women) or } 5 \text { or more drinks (for } \\
\text { men) on a single occasion, or "heavy drinking," which is defined as } 7 \text { or more } \\
\text { drinks a week (for women) or } 14 \text { or more drinks a week (for men). }\end{array}$ & $\begin{array}{l}\text { Add health: } \\
\text { H4TO37, H4TO39, } \\
\text { and H4TO40 }\end{array}$ \\
\hline Marijuana & $\begin{array}{l}\text { An indicator variable equal to } 1 \text { for respondents who have smoked marijuana this } \\
\text { year and zero otherwise }(\mathrm{H} 4 \mathrm{TO} 70=1 \text { to } 6) \text {. }\end{array}$ & Add health: H4TO70 \\
\hline Drugs & $\begin{array}{l}\text { An indicator variable equal to } 1 \text { for respondents who have used illegal drugs in } \\
\text { their lives and report that they used their favorite illegal drug during the past year } \\
\text { and zero otherwise (H4TO98 }=1 \text { to } 6 \text { ). }\end{array}$ & Add health: H4TO98 \\
\hline $\begin{array}{l}\text { Neurotic } \\
\text { personality }\end{array}$ & $\begin{array}{l}\text { One of the "big } 5 \text { " personality traits. The first factor produced through a factor } \\
\text { analysis of } 4 \text { questions from a standard personality scale. }\end{array}$ & $\begin{array}{l}\text { Add health: H4PE4, } \\
\text { H4PE12, H4PE20, } \\
\text { H4PE28 }\end{array}$ \\
\hline $\begin{array}{l}\text { Extraverted } \\
\text { personality }\end{array}$ & $\begin{array}{l}\text { One of the "big } 5 \text { " personality traits. The first factor produced through a factor } \\
\text { analysis of } 4 \text { questions from a standard personality scale. }\end{array}$ & $\begin{array}{l}\text { Add health: H4PE1, } \\
\text { H4PE9, H4P17, } \\
\text { H4PE25 }\end{array}$ \\
\hline $\begin{array}{l}\text { Conscientious } \\
\text { personality }\end{array}$ & $\begin{array}{l}\text { One of the "big } 5 \text { " personality traits. The first factor produced through a factor } \\
\text { analysis of } 4 \text { questions from a standard personality scale. }\end{array}$ & $\begin{array}{l}\text { Add health: H4PE3, } \\
\text { H4PE11, H4PE19, } \\
\text { H4PE27 }\end{array}$ \\
\hline $\begin{array}{c}\text { Open } \\
\text { personality }\end{array}$ & $\begin{array}{l}\text { One of the "big 5" personality traits. The first factor produced through a factor } \\
\text { analysis of } 3 \text { questions from a standard personality scale. }\end{array}$ & $\begin{array}{l}\text { Add health: H4PE5, } \\
\text { H4PE13, H4PE21 }\end{array}$ \\
\hline $\begin{array}{l}\text { Agreeable } \\
\text { personality }\end{array}$ & $\begin{array}{l}\text { One of the "big } 5 \text { " personality traits. The first factor produced through a factor } \\
\text { analysis of } 4 \text { questions from a standard personality scale. }\end{array}$ & $\begin{array}{l}\text { Add health: H4PE2, } \\
\text { H4PE10, H4PE18, } \\
\text { H4PE26 }\end{array}$ \\
\hline $\begin{array}{l}\text { Childhood } \\
\text { depression }\end{array}$ & $\begin{array}{l}\text { A scale measure of depression measured during respondent's adolescence, adapted } \\
\text { from the Center for Epidemiologic Studies Depression Scale (CES-D). It is the } \\
\text { sum of } 20 \text { questions, each with a response coded to a number between } 0 \text { (less } \\
\text { depression) and } 3 \text { (more depression). }\end{array}$ & $\begin{array}{l}\text { Add health: H1FS1 } \\
\text { through H1FS19 }\end{array}$ \\
\hline $\begin{array}{l}\text { Childhood } \\
\text { suicidal } \\
\text { thoughts }\end{array}$ & $\begin{array}{l}\text { An indicator variable equal to } 1 \text { for respondents who, as adolescents, said they had } \\
\text { seriously thought about committing suicide during the past } 12 \text { months (H1SU1 = } \\
\text { 1). }\end{array}$ & Add health: H1SU1 \\
\hline $\begin{array}{l}\text { Childhood } \\
\text { suicide } \\
\text { attempts }\end{array}$ & $\begin{array}{l}\text { A measure taken during respondents" adolescence of the number of times during } \\
\text { the } 12 \text { months prior to the data collection interview that the respondent attempted } \\
\text { to commit suicide with values of } 1 \text { representing " } 1 \text { time" and values of } 4 \\
\text { representing " } 6 \text { or more times" (H1SU2 }<5 \text { ). }\end{array}$ & Add health: H1SU2 \\
\hline $\begin{array}{l}\text { Childhood } \\
\text { fam/friend } \\
\text { suicide }\end{array}$ & $\begin{array}{l}\text { An indicator variable equal to } 1 \text { for respondents who, as adolescents, had a friend } \\
\text { or family member who committed suicide in the } 12 \text { months prior to the data } \\
\text { collection interview (H1SU5 = } 1 \text { or H1SU7 }=1 \text { ). }\end{array}$ & $\begin{array}{l}\text { Add health: H1SU5 } \\
\text { and H1SU7 }\end{array}$ \\
\hline $\begin{array}{l}\text { Childhood } \\
\text { friends care }\end{array}$ & $\begin{array}{l}\text { An indicator variable equal to } 1 \text { for respondents who, as adolescents, felt that their } \\
\text { friends care about them "quite a bit" or "very much" and zero otherwise (H1PR } 4= \\
4 \text { or 5). }\end{array}$ & Add health: H1PR4 \\
\hline $\begin{array}{l}\text { Childhood } \\
\text { parents care }\end{array}$ & $\begin{array}{l}\text { An indicator variable equal to } 1 \text { for respondents who, as adolescents, felt that their } \\
\text { parents cared about them "quite a bit" or "very much" and zero otherwise (H1PR3 } \\
=4 \text { or } 5 \text { ). }\end{array}$ & Add health: H1PR3 \\
\hline $\begin{array}{l}\text { Childhood } \\
\text { physical abuse }\end{array}$ & $\begin{array}{l}\text { A measure of the frequency of physical abuse adult respondents remember } \\
\text { experiencing when they were children on a scale from } 1 \text { (one time) to } 5 \text { (more than } \\
\text { ten times). }\end{array}$ & Add health: H4MA3 \\
\hline $\begin{array}{l}\text { Childhood } \\
\text { sexual abuse }\end{array}$ & $\begin{array}{l}\text { A measure of the frequency of sexual abuse adult respondents remember } \\
\text { experiencing when they were children on a scale from } 1 \text { (one time) to } 5 \text { (more than } \\
\text { ten times). }\end{array}$ & Add health: H4MA5 \\
\hline
\end{tabular}


Figure 1

Add Health Respondents Arranged by Scores on a Depression Scale and a "High Status Job" Factor

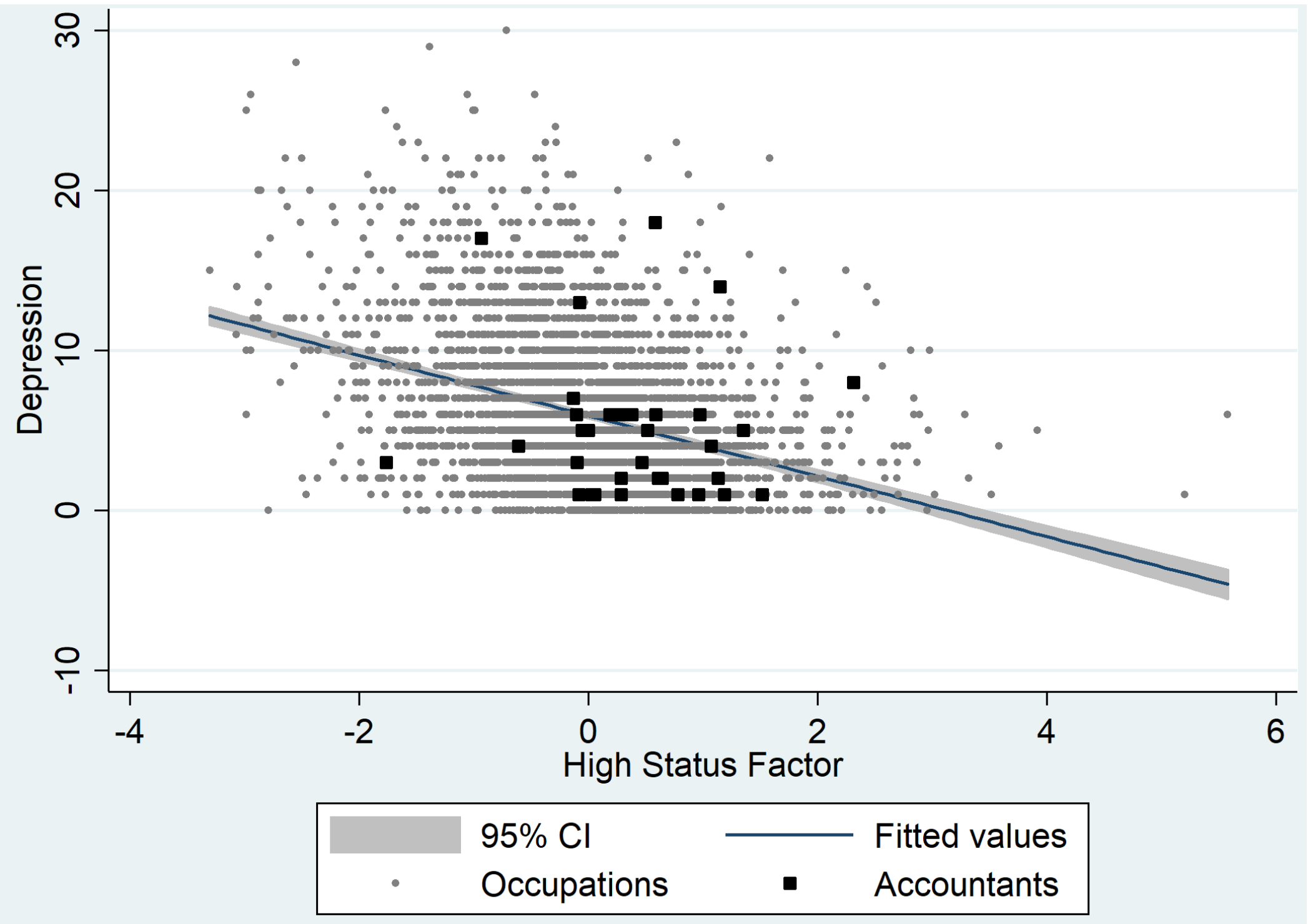


Table 1

Descriptive Statistics for Model 1 Variables

Panel A: People Working 10+ Hours per Week

\begin{tabular}{lrrrrrrrrr} 
& \multicolumn{4}{c}{ Non-accountants } & \multicolumn{4}{c}{ Accountants } \\
& $\mathrm{N}$ & $\mathrm{mean}$ & $\mathrm{p} 50$ & $\mathrm{~min}$ & $\max$ & $\mathrm{sd}$ & $\mathrm{N}$ & mean & Diff \\
\hline Job dissatisfaction & 35,038 & 0.12 & 0.00 & 0.00 & 1.00 & 0.32 & 351 & 0.07 & $-0.05 * * *$ \\
Unhappiness & 35,038 & 0.09 & 0.00 & 0.00 & 1.00 & 0.28 & 351 & 0.04 & $-0.05^{* * *}$ \\
Accounting & 35,038 & 0.00 & 0.00 & 0.00 & 0.00 & 0.00 & 351 & 1.00 & 1.00 \\
Income & 30,224 & 2.38 & 1.74 & 0.02 & 48.01 & 3.00 & 306 & 3.42 & $1.04 * * *$ \\
Prestige & 34,425 & 43.44 & 43.00 & 16.00 & 80.00 & 12.95 & 351 & 60.00 & $16.56^{* * *}$ \\
Hours worked & 35,038 & 41.89 & 40.00 & 10.00 & 89.00 & 13.43 & 351 & 43.41 & $1.52^{*}$ \\
Long hours & 35,038 & 0.13 & 0.00 & 0.00 & 1.00 & 0.34 & 351 & 0.14 & 0.01 \\
High school grad. & 35,038 & 0.61 & 1.00 & 0.00 & 1.00 & 0.49 & 351 & 0.30 & $-0.31^{* * *}$ \\
Bachelor's degree & 35,038 & 0.17 & 0.00 & 0.00 & 1.00 & 0.38 & 351 & 0.54 & $0.37 * * *$ \\
Master's degree & 35,038 & 0.09 & 0.00 & 0.00 & 1.00 & 0.28 & 351 & 0.15 & $0.07 * * *$ \\
Female & 35,038 & 0.47 & 0.00 & 0.00 & 1.00 & 0.50 & 351 & 0.54 & $0.07 * *$ \\
Age & 34,933 & 40.23 & 39.00 & 18.00 & 89.00 & 12.98 & 348 & 41.28 & $1.05 *$ \\
Married & 35,038 & 0.61 & 1.00 & 0.00 & 1.00 & 0.49 & 351 & 0.68 & $0.06 * *$ \\
Ever divorced & 35,038 & 0.13 & 0.00 & 0.00 & 1.00 & 0.34 & 351 & 0.12 & -0.02 \\
Child income low & 35,038 & 0.25 & 0.00 & 0.00 & 1.00 & 0.43 & 351 & 0.19 & $-0.05 * *$ \\
Child income high & 35,038 & 0.15 & 0.00 & 0.00 & 1.00 & 0.35 & 351 & 0.17 & 0.02 \\
Close friends & 35,038 & 0.27 & 0.00 & 0.00 & 1.00 & 0.44 & 351 & 0.26 & 0.00 \\
Close family & 35,038 & 0.33 & 0.00 & 0.00 & 1.00 & 0.47 & 351 & 0.37 & 0.03 \\
Weekly church & 35,038 & 0.25 & 0.00 & 0.00 & 1.00 & 0.43 & 351 & 0.32 & $0.07 * * *$ \\
\hline
\end{tabular}

Panel B: People Working 30+ Hours per Week and with Bachelor's or Higher Degree

\begin{tabular}{lcrrrrrrrr} 
& \multicolumn{4}{c}{ Non-accountants } & \multicolumn{4}{c}{ Accountants } \\
& $\mathrm{N}$ & mean & $\mathrm{p} 50$ & $\mathrm{~min}$ & $\mathrm{max}$ & $\mathrm{sd}$ & $\mathrm{N}$ & mean & Diff \\
\hline Job dissatisfaction & 8,448 & 0.09 & 0.00 & 0.00 & 1.00 & 0.29 & 229 & 0.07 & -0.02 \\
Unhappiness & 8,448 & 0.05 & 0.00 & 0.00 & 1.00 & 0.22 & 229 & 0.04 & -0.01 \\
Accounting & 8,448 & 0.00 & 0.00 & 0.00 & 0.00 & 0.00 & 229 & 1.00 & 1.00 \\
Income & 7,516 & 4.04 & 2.87 & 0.03 & 48.01 & 4.54 & 203 & 4.25 & 0.22 \\
Prestige & 8,327 & 53.98 & 54.00 & 16.00 & 80.00 & 12.88 & 229 & 60.00 & $6.02^{* * *}$ \\
Hours worked & 8,448 & 46.64 & 42.00 & 30.00 & 89.00 & 10.91 & 229 & 46.10 & -0.54 \\
Long hours & 8,448 & 0.18 & 0.00 & 0.00 & 1.00 & 0.38 & 229 & 0.17 & -0.01 \\
High school grad. & 8,448 & 0.00 & 0.00 & 0.00 & 0.00 & 0.00 & 229 & 0.00 & 0.00 \\
Bachelor's degree & 8,448 & 0.66 & 1.00 & 0.00 & 1.00 & 0.47 & 229 & 0.77 & $0.11^{* * *}$ \\
Master's degree & 8,448 & 0.34 & 0.00 & 0.00 & 1.00 & 0.47 & 229 & 0.23 & $-0.11 * * *$ \\
Female & 8,448 & 0.43 & 0.00 & 0.00 & 1.00 & 0.50 & 229 & 0.43 & -0.01 \\
Age & 8,425 & 41.51 & 41.00 & 19.00 & 86.00 & 11.42 & 227 & 40.51 & -1.00 \\
Married & 8,448 & 0.66 & 1.00 & 0.00 & 1.00 & 0.47 & 229 & 0.68 & 0.01 \\
Ever divorced & 8,448 & 0.11 & 0.00 & 0.00 & 1.00 & 0.31 & 229 & 0.09 & -0.01 \\
Child income low & 8,448 & 0.19 & 0.00 & 0.00 & 1.00 & 0.39 & 229 & 0.17 & -0.01 \\
Child income high & 8,448 & 0.23 & 0.00 & 0.00 & 1.00 & 0.42 & 229 & 0.19 & -0.04 \\
Close friends & 8,448 & 0.27 & 0.00 & 0.00 & 1.00 & 0.44 & 229 & 0.28 & 0.01 \\
Close family & 8,448 & 0.29 & 0.00 & 0.00 & 1.00 & 0.45 & 229 & 0.38 & $0.09 * * *$ \\
Weekly church & 8,448 & 0.28 & 0.00 & 0.00 & 1.00 & 0.45 & 229 & 0.31 & 0.03
\end{tabular}

Data summarized in this table come from the GSS. Job dissatisfaction and unhappiness are indicator variables for low job satisfaction and general unhappiness. Accounting is an indicator for people whose occupation is accounting. Income is in tens of thousands of 1986 dollars. Prestige is an occupational prestige scale updated in 1970, 1989, and 
2012. Hours worked is from the most recent week. Long hours is an indicator for more than 55 hours worked. High school grad., bachelor's degree, and master's degree are indicators for highest degree at these levels. Female is an indicator for women. Age is in years. Married and ever divorced are indicators for these relationship histories. Child income low and high are indicators for low or high family income when the respondent was 16 years old. Close friends and family are indicators for monthly or more frequent social interactions with friends or family. Weekly church is an indicator for attending church at least weekly. Data on the left are for non-accountants while data on the right are for only accountants. The column labelled "Diff" is the difference between the mean value for nonaccountants and accountants. Stars in this column represent statistically significant two-tailed differences at the $\mathrm{p}<$ $0.01(* *), 0.05(* *)$, and $0.10(*)$ levels. Detailed variable definitions are in the Appendix. 
Table 2

Univariate Pairwise Pearson Correlation Coefficients for Model 1 Variables

\begin{tabular}{|c|c|c|c|c|c|c|c|c|c|c|c|c|c|c|c|c|c|c|c|c|}
\hline & & 1 & 2 & 3 & 4 & 5 & 6 & 7 & 8 & 9 & 10 & 11 & 12 & 13 & 14 & 15 & 16 & 17 & 18 & 19 \\
\hline$\overline{1}$ & Job dissatisfaction & 1.00 & & & & & & & & & & & & & & & & & & \\
\hline 2 & Unhappiness & $0.17 *$ & 1.00 & & & & & & & & & & & & & & & & & \\
\hline 3 & Accounting & -0.01 & -0.02 & 1.00 & & & & & & & & & & & & & & & & \\
\hline 4 & Income & $-0.07 *$ & $-0.06^{*}$ & 0.04 & 1.00 & & & & & & & & & & & & & & & \\
\hline 5 & Prestige & $-0.11 * *$ & $-0.09 * *$ & $0.12^{* *}$ & $0.30^{* *}$ & 1.00 & & & & & & & & & & & & & & \\
\hline 6 & Hours worked & $-0.05 * *$ & $-0.03 *$ & 0.01 & $0.25 * *$ & $0.15 * *$ & 1.00 & & & & & & & & & & & & & \\
\hline 7 & Long hours & $-0.03 *$ & -0.02 & 0.00 & $0.16 * *$ & $0.08 *$ & $0.71 * * *$ & 1.00 & & & & & & & & & & & & \\
\hline 8 & High school grad. & 0.02 & $0.01 *$ & $-0.06^{*}$ & $-0.18 * *$ & $-0.26 * * *$ & -0.04 & -0.02 & 1.00 & & & & & & & & & & & \\
\hline 9 & Bachelor's degree & -0.03 & $-0.05^{*}$ & $0.09 * *$ & $0.14 * *$ & $0.26 * * *$ & $0.05^{* *}$ & 0.02 & $-0.58 * * *$ & 1.00 & & & & & & & & & & \\
\hline 10 & Master's degree & -0.04 & $-0.04 *$ & 0.03 & $0.26 * *$ & $0.38 * *$ & $0.07 *$ & 0.05 & $-0.39 * * *$ & $-0.15^{* *}$ & 1.00 & & & & & & & & & \\
\hline 11 & Female & 0.00 & 0.01 & 0.01 & $-0.22 *$ & $-0.01 * *$ & $-0.24 * *$ & $-0.16 * *$ & $0.06 * *$ & 0.00 & $-0.01 *$ & 1.00 & & & & & & & & \\
\hline 12 & Age & $-0.09 *$ & 0.00 & 0.00 & $0.19 * *$ & $0.10^{* *}$ & 0.03 & $0.03 *$ & $-0.13^{* *}$ & 0.00 & $0.11 * *$ & -0.02 & 1.00 & & & & & & & \\
\hline 13 & Married & $-0.06^{*}$ & $-0.12 * *$ & 0.01 & $0.15^{* *}$ & $0.14 * * *$ & $0.07 * * *$ & $0.04 * *$ & $-0.06 * *$ & $0.02 * * *$ & $0.07 * *$ & $-0.09 * *$ & $0.25^{* *}$ & 1.00 & & & & & & \\
\hline 14 & Ever divorced & $-0.02 *$ & -0.03 & 0.00 & $0.04 *$ & 0.00 & 0.04 & 0.03 & 0.03 & -0.05 & -0.01 & -0.01 & $0.19^{* *}$ & $0.29 * * *$ & 1.00 & & & & & \\
\hline 15 & Child income low & $0.04 * *$ & $0.06^{* *} *$ & -0.01 & -0.03 & $-0.06^{*}$ & -0.01 & 0.00 & -0.01 & $-0.07 *$ & -0.04 & $-0.01 *$ & $0.11 *$ & 0.04 & 0.01 & 1.00 & & & & \\
\hline 16 & Child income high & $-0.02 * *$ & -0.02 & 0.00 & 0.08 & $0.09 * *$ & $0.03 * *$ & $0.03 * * *$ & $-0.08 * * *$ & $0.11 * *$ & $0.09 * *$ & $-0.02 * *$ & $-0.05^{* *}$ & -0.02 & $-0.02 *$ & $-0.23 * * *$ & 1.00 & & & \\
\hline 17 & Close friends & 0.01 & $-0.02 *$ & 0.00 & $-0.04 *$ & $-0.02 * * *$ & -0.03 & -0.02 & $0.03 *$ & 0.01 & -0.01 & 0.01 & $-0.18 * *$ & $-0.16^{*}$ & $-0.06^{* * *}$ & -0.05 & 0.03 & 1.00 & & \\
\hline 18 & Close family & 0.00 & $-0.03 * *$ & 0.01 & -0.05 & -0.03 & $-0.03 *$ & -0.02 & $0.05 * * *$ & -0.03 & $-0.05 *$ & $0.04 *$ & $-0.06^{* *}$ & $-0.01 *$ & -0.03 & 0.00 & $-0.01^{*}$ & $0.38 * *$ & 1.00 & \\
\hline 19 & Weekly church & -0.05 & -0.04 & $0.02 *$ & 0.00 & $0.05^{*}$ & -0.05 & -0.03 & -0.03 & $0.04 *$ & 0.03 & 0.07 & $0.12 * *$ & $0.11 * *$ & -0.02 & 0.04 & -0.04 & $-0.02 *$ & $0.03 * *$ & 1.00 \\
\hline
\end{tabular}

Data summarized in this table come from the GSS. Job dissatisfaction and unhappiness are indicator variables for low job satisfaction and general unhappiness.

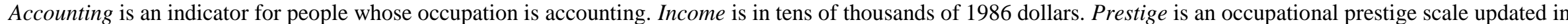

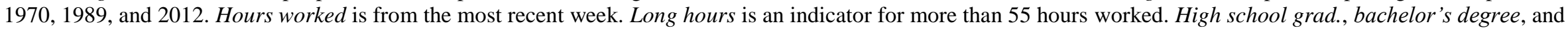
master's degree are indicators for highest degree at these levels. Female is an indicator for women. Age is in years. Married and ever divorced are indicators for these relationship histories. Child income low and high are indicators for low or high family income when the respondent was 16 years old. Close friends and family are indicators for monthly or more frequent social interactions with friends or family. Weekly church is an indicator for attending church at least weekly. Stars represent statistically significant two-tailed coefficients at the $\mathrm{p}<0.01(* * *), 0.05(* *)$, and $0.10(*)$ levels. Detailed variable definitions are in the Appendix. 
Table 3

Models of Workplace Misery in the GSS

Working 10+ hours a week.

\begin{tabular}{|c|c|c|c|c|c|c|c|c|c|c|c|c|}
\hline & \multicolumn{3}{|c|}{ Job dissatisfaction } & \multicolumn{3}{|c|}{ Unhappiness } & \multicolumn{3}{|c|}{ Job dissatisfaction } & \multicolumn{3}{|c|}{ Unhappiness } \\
\hline & 1 & 2 & 3 & 4 & 5 & 6 & 7 & 8 & 9 & 10 & 11 & 12 \\
\hline Accounting & 0.000 & 0.000 & -0.027 & $-0.020 * *$ & $-0.018 *$ & $-0.075^{* *}$ & -0.009 & -0.009 & 0.086 & $-0.022 * *$ & $-0.019 *$ & -0.029 \\
\hline Income & $-0.004 * * *$ & $-0.003 * * *$ & $-0.002 * * *$ & $-0.003 * * *$ & $-0.002 * * *$ & $-0.002 * * *$ & $-0.002 * * *$ & $-0.001 *$ & -0.001 & $-0.002 * * *$ & $-0.002 * * *$ & $-0.002 * * *$ \\
\hline Prestige & $-0.003 * * *$ & $-0.002 * * *$ & -0.001 & $-0.001 * * *$ & $-0.001 * * *$ & $0.005^{*}$ & $-0.002 * * *$ & $-0.002 * * *$ & 0.087 & $-0.001 * * *$ & $-0.001 * * *$ & -0.020 \\
\hline Hours worked & $-0.001 * *$ & $-0.001 * * *$ & $-0.001 * * *$ & 0.000 & 0.000 & 0.000 & $-0.002 * * *$ & $-0.002 * * *$ & $-0.002 * * *$ & 0.000 & 0.000 & 0.000 \\
\hline Long hours & 0.001 & 0.003 & 0.007 & 0.007 & 0.005 & 0.006 & $0.026^{*}$ & $0.027 *$ & $0.027 *$ & 0.001 & 0.001 & -0.003 \\
\hline High school grad. & -0.001 & -0.004 & 0.003 & $-0.045 * * *$ & $-0.040 * * *$ & $-0.030 * * *$ & & & & & & \\
\hline Bachelor's degree & 0.008 & 0.007 & $0.016^{*}$ & $-0.061 * * *$ & $-0.054 * * *$ & $-0.038 * * *$ & -0.003 & -0.007 & -0.004 & $-0.010 *$ & -0.008 & $-0.015 * *$ \\
\hline Master's degree & 0.014 & $0.018 *$ & $0.020 *$ & $-0.046 * * *$ & $-0.041 * * *$ & $-0.022 * *$ & & & & & & \\
\hline Female & & $-0.008 *$ & $-0.013 * *$ & & -0.004 & 0.002 & & -0.005 & 0.012 & & $-0.012 * *$ & -0.001 \\
\hline Age & & $-0.002 * * *$ & $-0.002 * * *$ & & $0.001 * * *$ & $0.001 * * *$ & & $-0.001 * *$ & 0.000 & & $0.001 * * *$ & $0.001 * * *$ \\
\hline Married & & $-0.020 * * *$ & $-0.021 * * *$ & & $-0.067 * * *$ & $-0.069 * * *$ & & $-0.015^{*}$ & -0.008 & & $-0.047 * * *$ & $-0.045 * * *$ \\
\hline Ever divorced & & 0.004 & 0.004 & & -0.001 & 0.000 & & $0.024 *$ & $0.024 * *$ & & -0.006 & -0.001 \\
\hline Child income low & & $0.034 * * *$ & $0.041 * * *$ & & $0.034 * * *$ & $0.037 * * *$ & & $0.021 * *$ & $0.028 * * *$ & & $0.019 * *$ & $0.021 * * *$ \\
\hline Child income high & & -0.004 & 0.006 & & 0.002 & 0.003 & & -0.013 & -0.008 & & 0.000 & -0.001 \\
\hline Close friends & & -0.006 & -0.005 & & $-0.017 * * *$ & $-0.022 * * *$ & & -0.004 & -0.010 & & $-0.017 * * *$ & $-0.020 * * *$ \\
\hline Close family & & -0.005 & -0.004 & & $-0.011 * * *$ & $-0.017 * * *$ & & 0.011 & 0.014 & & -0.009 & $-0.010^{*}$ \\
\hline Weekly church & & $-0.025 * * *$ & $-0.026 * * *$ & & $-0.019 * * *$ & $-0.017 * * *$ & & $-0.032 * * *$ & $-0.034 * * *$ & & $-0.016 * * *$ & $-0.013 * *$ \\
\hline Constant & $0.259 * * *$ & $0.346 * * *$ & $0.217^{*}$ & $0.202 * * *$ & $0.208 * * *$ & -0.118 & $0.308 * * *$ & $0.357 * * *$ & -5.143 & $0.132 * * *$ & $0.134 * * *$ & 1.289 \\
\hline $\mathrm{N}$ & 29,454 & 29,454 & 29,454 & 29,454 & 29,454 & 29,454 & 7,512 & 7,512 & 7,512 & 7,512 & 7,512 & 7,512 \\
\hline $\mathrm{R}^{2}$ & 0.014 & 0.025 & 0.058 & 0.013 & 0.031 & 0.060 & 0.015 & 0.021 & 0.116 & 0.006 & 0.021 & 0.109 \\
\hline Occ. \& Year FE & No & No & Yes & No & No & Yes & No & No & Yes & No & No & Yes \\
\hline
\end{tabular}

Data summarized in this table come from the GSS. We estimate models using OLS. Dependent variables are job dissatisfaction and unhappiness, which are indicator variables for low job satisfaction and general unhappiness. Accounting is an indicator for people whose occupation is accounting. Income is in tens of thousands of 1986 dollars. Prestige is an occupational prestige scale updated in 1970, 1989, and 2012. Hours worked is from the most recent week. Long hours is an indicator for more than 55 hours worked. High school grad., bachelor's degree, and master's degree are indicators for highest degree at these levels. Female is an indicator for women. Age is in years. Married and ever divorced are indicators for these relationship histories. Child income low and high are indicators for low or high family income when the respondent was 16 years old. Close friends and family are indicators for monthly or more frequent social interactions with friends or family. Weekly church is an indicator attending church at least weekly. Stars represent statistically significant two-tailed coefficients at the $\mathrm{p}<0.01$ $(* * *), 0.05(* *)$, and $0.10(*)$ levels. Detailed variable definitions are in the Appendix.

Working 30+ hours/week and holding at least a bachelor's degree

.


Table 4

Descriptive Statistics for Model 2 Variables

Panel A: All Occupations

\begin{tabular}{|c|c|c|c|c|c|c|c|c|}
\hline & \multicolumn{5}{|c|}{ Non-accountants } & \multicolumn{3}{|c|}{ Accountants } \\
\hline & $\mathrm{N}$ & mean & p50 & $\min$ & $\max$ & sd & Value & $\%$ ile \\
\hline Job dissatisfaction & 320 & 0.12 & 0.10 & 0.00 & 0.62 & 0.10 & 0.08 & $36 \%$ \\
\hline Unhappiness & 338 & 0.13 & 0.11 & 0.00 & 0.55 & 0.10 & 0.05 & $24 \%$ \\
\hline Mental health bad & 297 & 3.58 & 3.21 & 0.00 & 19.09 & 2.36 & 1.96 & $23 \%$ \\
\hline Suicide rate & 272 & 0.70 & 0.07 & 0.00 & 143.33 & 8.69 & 0.11 & $62 \%$ \\
\hline Status (factor) & 196 & -0.01 & -0.03 & -2.08 & 2.12 & 0.98 & 1.14 & $84 \%$ \\
\hline Blue collar (factor) & 196 & 0.00 & -0.17 & -1.85 & 2.55 & 0.97 & -0.60 & $30 \%$ \\
\hline Repetitive (factor) & 196 & -0.01 & 0.08 & -2.45 & 1.95 & 0.90 & 0.95 & $87 \%$ \\
\hline Security (factor) & 196 & 0.00 & -0.01 & -2.49 & 2.84 & 0.89 & -0.11 & $47 \%$ \\
\hline Income & 516 & 4.90 & 4.18 & 1.80 & 18.32 & 2.48 & 6.39 & $78 \%$ \\
\hline Proportion $40+$ hours & 517 & 0.85 & 0.93 & 0.05 & 1.00 & 0.19 & 0.95 & $58 \%$ \\
\hline Competitive pressure & 517 & 3.02 & 3.02 & 1.50 & 4.64 & 0.53 & 3.38 & $73 \%$ \\
\hline Time pressure & 517 & 3.83 & 3.88 & 1.91 & 4.94 & 0.47 & 3.82 & $44 \%$ \\
\hline Time off easy & 240 & 1.17 & 1.17 & 0.24 & 2.00 & 0.32 & 1.37 & $74 \%$ \\
\hline Work related travel & 503 & 26.56 & 24.33 & 0.00 & 177.39 & 17.01 & 30.37 & $70 \%$ \\
\hline Job security & 256 & 1.39 & 1.38 & 0.47 & 2.00 & 0.26 & 1.49 & $68 \%$ \\
\hline Promotions fair & 229 & 0.99 & 0.99 & 0.25 & 1.74 & 0.30 & 0.91 & $37 \%$ \\
\hline Active learning & 518 & 3.01 & 3.00 & 1.12 & 5.25 & 0.74 & 3.69 & $79 \%$ \\
\hline On the job training & 517 & 3.77 & 3.72 & 1.49 & 7.03 & 0.93 & 4.63 & $81 \%$ \\
\hline Free to make decisions & 517 & 4.08 & 4.14 & 2.60 & 5.00 & 0.44 & 4.06 & $42 \%$ \\
\hline Adaptability & 518 & 3.91 & 3.94 & 2.42 & 4.77 & 0.37 & 3.85 & $41 \%$ \\
\hline Repeat tasks & 518 & 3.27 & 3.24 & 1.41 & 4.92 & 0.64 & 4.17 & $90 \%$ \\
\hline Standards & 518 & 3.41 & 3.48 & 1.65 & 4.68 & 0.58 & 4.43 & $97 \%$ \\
\hline Creative thinking & 518 & 3.23 & 3.23 & 1.69 & 4.84 & 0.65 & 3.05 & $41 \%$ \\
\hline Indoor & 518 & 3.79 & 4.16 & 1.05 & 5.00 & 1.00 & 4.59 & $78 \%$ \\
\hline Sitting & 518 & 2.97 & 2.92 & 1.05 & 4.98 & 1.08 & 4.61 & $93 \%$ \\
\hline Awkward positions & 518 & 2.10 & 1.86 & 1.00 & 4.58 & 0.83 & 1.43 & $24 \%$ \\
\hline Physical activity & 518 & 2.94 & 3.07 & 1.07 & 4.77 & 0.92 & 1.43 & $5 \%$ \\
\hline Education requirement & 517 & 4.05 & 3.32 & 1.35 & 11.32 & 2.20 & 6.17 & $81 \%$ \\
\hline Male & 417 & 0.63 & 0.68 & 0.02 & 1.00 & 0.29 & 0.40 & $25 \%$ \\
\hline Age & 417 & 42.05 & 42.38 & 23.29 & 52.98 & 4.24 & 42.89 & $57 \%$ \\
\hline Divorced & 417 & 0.11 & 0.11 & 0.01 & 0.26 & 0.04 & 0.10 & $36 \%$ \\
\hline Monthly church & 355 & 0.45 & 0.46 & 0.00 & 1.00 & 0.16 & 0.55 & $79 \%$ \\
\hline Gun ownership & 301 & 0.38 & 0.36 & 0.00 & 1.00 & 0.18 & 0.39 & $58 \%$ \\
\hline
\end{tabular}


Table 4 (continued)

Descriptive Statistics for Model 2 Variables

Panel B: Occupations Requiring "Some College"

\begin{tabular}{|c|c|c|c|c|c|c|c|c|}
\hline & \multicolumn{5}{|c|}{ Non-accountants } & \multicolumn{3}{|c|}{ Accountants } \\
\hline & $\mathrm{N}$ & mean & $\mathrm{p} 50$ & $\min$ & $\max$ & sd & Value & $\%$ ile \\
\hline Job dissatisfaction & 146 & 0.09 & 0.08 & 0.00 & 0.36 & 0.08 & 0.08 & $47 \%$ \\
\hline Unhappiness & 154 & 0.09 & 0.07 & 0.00 & 0.55 & 0.09 & 0.05 & $36 \%$ \\
\hline Mental health bad & 137 & 3.06 & 2.87 & 0.00 & 12.43 & 1.93 & 1.96 & $31 \%$ \\
\hline Suicide rate & 103 & 0.18 & 0.08 & 0.01 & 2.56 & 0.33 & 0.11 & $60 \%$ \\
\hline Status (factor) & 77 & 0.95 & 0.98 & -0.51 & 2.12 & 0.52 & 1.14 & $60 \%$ \\
\hline Blue collar (factor) & 77 & -0.17 & -0.25 & -1.43 & 1.12 & 0.55 & -0.60 & $26 \%$ \\
\hline Repetitive (factor) & 77 & -0.23 & -0.19 & -2.42 & 1.49 & 0.85 & 0.95 & $92 \%$ \\
\hline Security (factor) & 77 & -0.08 & -0.20 & -2.49 & 2.58 & 1.04 & -0.11 & $53 \%$ \\
\hline Income & 208 & 6.83 & 6.41 & 2.59 & 18.32 & 2.69 & 6.39 & $49 \%$ \\
\hline Proportion $40+$ hours & 208 & 0.90 & 0.95 & 0.13 & 1.00 & 0.14 & 0.95 & $49 \%$ \\
\hline Competitive pressure & 208 & 3.21 & 3.23 & 1.50 & 4.40 & 0.48 & 3.38 & $62 \%$ \\
\hline Time pressure & 208 & 3.84 & 3.82 & 2.88 & 4.94 & 0.38 & 3.82 & $50 \%$ \\
\hline Time off easy & 107 & 1.23 & 1.25 & 0.28 & 2.00 & 0.33 & 1.37 & $68 \%$ \\
\hline Work related travel & 205 & 29.14 & 26.92 & 0.00 & 177.39 & 17.78 & 30.37 & $61 \%$ \\
\hline Job security & 115 & 1.39 & 1.39 & 0.66 & 1.92 & 0.26 & 1.49 & $69 \%$ \\
\hline Promotions fair & 101 & 1.05 & 1.02 & 0.43 & 1.70 & 0.28 & 0.91 & $29 \%$ \\
\hline Active learning & 209 & 3.68 & 3.69 & 2.25 & 5.25 & 0.49 & 3.69 & $50 \%$ \\
\hline On the job training & 208 & 3.90 & 3.88 & 2.04 & 6.04 & 0.73 & 4.63 & $83 \%$ \\
\hline Free to make decisions & s 208 & 4.28 & 4.29 & 2.89 & 4.96 & 0.32 & 4.06 & $22 \%$ \\
\hline Adaptability & 209 & 4.11 & 4.14 & 3.15 & 4.71 & 0.29 & 3.85 & $16 \%$ \\
\hline Repeat tasks & 209 & 3.20 & 3.13 & 1.82 & 4.68 & 0.61 & 4.17 & $92 \%$ \\
\hline Standards & 209 & 3.61 & 3.68 & 1.77 & 4.66 & 0.54 & 4.43 & $95 \%$ \\
\hline Creative thinking & 209 & 3.67 & 3.68 & 2.07 & 4.84 & 0.54 & 3.05 & $14 \%$ \\
\hline Indoor & 209 & 4.40 & 4.50 & 3.01 & 5.00 & 0.38 & 4.59 & $62 \%$ \\
\hline Sitting & 209 & 3.73 & 3.82 & 1.58 & 4.92 & 0.75 & 4.61 & $89 \%$ \\
\hline Awkward positions & 209 & 1.64 & 1.53 & 1.00 & 3.62 & 0.51 & 1.43 & $39 \%$ \\
\hline Physical activity & 209 & 2.28 & 2.18 & 1.07 & 4.46 & 0.76 & 1.43 & $11 \%$ \\
\hline Education requirement & t 208 & 6.32 & 6.01 & 4.02 & 11.32 & 1.68 & 6.17 & $53 \%$ \\
\hline Male & 156 & 0.56 & 0.54 & 0.02 & 0.98 & 0.25 & 0.40 & $31 \%$ \\
\hline Age & 156 & 43.52 & 43.47 & 33.48 & 52.98 & 3.47 & 42.89 & $43 \%$ \\
\hline Divorced & 156 & 0.09 & 0.09 & 0.01 & 0.26 & 0.04 & 0.10 & $53 \%$ \\
\hline Monthly church & 159 & 0.46 & 0.46 & 0.00 & 1.00 & 0.16 & 0.55 & $78 \%$ \\
\hline Gun ownership & 133 & 0.37 & 0.36 & 0.00 & 0.91 & 0.17 & 0.39 & $63 \%$ \\
\hline
\end{tabular}

Data summarized in this table come from O*NET, GSS, OES, IPUMS-CPS, IPUMS-ATUS-X, CDC, and OES. Job dissatisfaction and unhappiness are occupation averages of indicator variables from the GSS for low job satisfaction and general unhappiness. Mental health bad is an occupation average of the days during the last month that GSS respondents reported having poor mental health. Suicide rate is an estimate of the suicide rate in an occupation per 1,000 occupation members using CDC and OES data. Status, blue collar, repetitive, and security are factors calculated from the model 2 independent variables. We describe the analysis that produced them in Table 5. Income is in tens of thousands of 2016 dollars from the OES. Proportion 40+ hours is the proportion of people working 40 or more hours per week from O*NET. Competitive pressure and time pressure are O*NET variables characterizing competitive and time pressure. Time off easy is an occupation average of an indicator variable for GSS respondents reporting that it is easy for them to take time off for emergencies. Work related travel is the percentage of people in the IPUMS-ATUS- $X$ who reported traveling for work in the prior 24 hours. Job security is an occupation average from GSS of an indicator for whether job security is good. Promotions fair is an occupation average from GSS of an indicator for agreement with "promotions are handled fairly" at work. Active learning, on the job training, free to make decisions, repeat tasks, standards, creative thinking, indoor, sitting, awkward positions, and physical activity 
are all occupation-level averages from $\mathrm{O}$ *NET questionnaires asking workers about the importance of these job features on a 5-point scale from "not important" to "extremely important" or about their frequency on a 5-point scale from "never" to "every day." Adaptability is an average from two O*NET variables, one measuring whether the job requires a person to be adaptive and flexible and another measuring whether the job requires shifting between different activities. Education requirement is an $\mathrm{O} * \mathrm{NET}$ variable measuring educational requirements on a 12-point scale from "less than a high school diploma" to "post-doctoral training." Male, age, and divorced come from IPUMS-CPS and represent the percentage of people in each occupation who are male or divorced, or the average age of people in an occupation. Monthly church is an occupational average from the GSS of an indicator variable for monthly (or more frequent) church attendance. Gun ownership is an occupational average from the GSS of an indicator for having a gun in the house. Data on the left are for non-accountants while data on the right are for only accountants. The column labelled "\%ile" is the percentile rank of the value for accounting relative to other occupations in the sample, with high values being near the $100^{\text {th }}$ percentile. Detailed variable definitions are in the Appendix. 
Table 5

Factor Analysis of Model 2 Variables

Panel A: First Ten Factors and Eigenvalues for Model 2 Variables

\begin{tabular}{lcccc} 
Factor & Eigenvalue & Difference & Proportion & Cumulative \\
\hline Factor1 & 6.42 & 2.71 & 0.31 & 0.31 \\
Factor2 & 3.71 & 1.71 & 0.18 & 0.50 \\
Factor3 & 2.01 & 0.57 & 0.10 & 0.60 \\
Factor4 & 1.44 & 0.37 & 0.07 & 0.67 \\
Factor5 & 1.07 & 0.08 & 0.05 & 0.72 \\
Factor6 & 0.99 & 0.18 & 0.05 & 0.77 \\
Factor7 & 0.82 & 0.08 & 0.04 & 0.81 \\
Factor8 & 0.74 & 0.11 & 0.04 & 0.84 \\
Factor9 & 0.63 & 0.16 & 0.03 & 0.87 \\
Factor10 & 0.47 & 0.15 & 0.02 & 0.90
\end{tabular}

Panel B: Variable Loadings on First Four Factors

\begin{tabular}{|c|c|c|c|c|c|}
\hline & Status & Blue Collar & Repetitive & Security & Uniqueness \\
\hline Income & 0.79 & 0.17 & -0.15 & 0.02 & 0.33 \\
\hline Proportion $40+$ hours & 0.46 & 0.49 & 0.32 & -0.11 & 0.44 \\
\hline Competitive pressure & 0.45 & 0.24 & -0.19 & -0.28 & 0.63 \\
\hline Time pressure & 0.30 & 0.34 & 0.42 & -0.01 & 0.62 \\
\hline Time off easy & 0.08 & 0.07 & 0.08 & -0.23 & 0.93 \\
\hline Work related travel & 0.35 & 0.38 & 0.21 & -0.17 & 0.66 \\
\hline Job security & 0.21 & 0.06 & -0.09 & 0.37 & 0.81 \\
\hline Promotions fair & 0.24 & 0.01 & -0.20 & 0.06 & 0.90 \\
\hline Active learning & 0.91 & 0.03 & -0.16 & 0.05 & 0.14 \\
\hline On the job training & 0.42 & 0.68 & 0.13 & -0.05 & 0.35 \\
\hline Free to make decisions & 0.55 & 0.18 & -0.21 & 0.17 & 0.59 \\
\hline Adaptability & 0.59 & -0.16 & -0.11 & 0.27 & 0.54 \\
\hline Repeat tasks & 0.04 & -0.24 & 0.50 & 0.01 & 0.69 \\
\hline Standards & 0.56 & 0.18 & 0.18 & 0.29 & 0.53 \\
\hline Creative thinking & 0.65 & 0.08 & -0.37 & -0.09 & 0.42 \\
\hline Indoor & 0.54 & -0.53 & 0.07 & 0.00 & 0.42 \\
\hline Sitting & 0.66 & -0.35 & 0.37 & -0.24 & 0.24 \\
\hline Awkward positions & -0.39 & 0.74 & -0.01 & 0.11 & 0.29 \\
\hline Physical activity & -0.65 & 0.50 & -0.25 & 0.40 & 0.11 \\
\hline Education requirement & 0.85 & -0.12 & -0.27 & 0.08 & 0.19 \\
\hline Male & -0.03 & 0.86 & -0.10 & -0.28 & 0.17 \\
\hline Age & 0.58 & 0.15 & 0.28 & 0.23 & 0.51 \\
\hline Divorced & -0.16 & 0.03 & 0.56 & 0.28 & 0.59 \\
\hline Monthly church & 0.13 & -0.29 & 0.04 & 0.27 & 0.82 \\
\hline Gun ownership & 0.09 & 0.44 & 0.13 & 0.23 & 0.73 \\
\hline
\end{tabular}

We produce this table using data from O*NET, GSS, OES, IPUMS-CPS, and IPUMS-ATUS-X. We perform this factor analysis using the iterated principal factors method. Income is in tens of thousands of 2016 dollars from the OES. Proportion $40+$ hours is the proportion of people working 40 or more hours per week from O*NET.

Competitive pressure and time pressure are $\mathrm{O}$ *NET variables characterizing competitive and time pressure. Time off easy is an occupation average of an indicator variable for GSS respondents reporting that it is easy for them to take time off for emergencies. Work related travel is the percentage of people in the IPUMS-ATUS-X who reported traveling for work in the prior 24 hours. Job security is an occupation average from GSS of an indicator for whether job security is good. Promotions fair is an occupation average from GSS of an indicator for agreement with "promotions are handled fairly" at work. Active learning, on the job training, free to make decisions, repeat tasks, 
standards, creative thinking, indoor, sitting, awkward positions, and physical activity are all occupation-level averages from $\mathrm{O}$ *NET questionnaires asking workers about the importance of these job features on a 5-point scale from "not important" to "extremely important" or about their frequency on a 5-point scale from "never" to "every day." Adaptability is an average from two $\mathrm{O} * \mathrm{NET}$ variables, one measuring whether the job requires a person to be adaptive and flexible and another measuring whether the job requires shifting between different activities. Education requirement is an $\mathrm{O}$ *NET variable measuring educational requirements on a 12-point scale from "less than a high school diploma" to "post-doctoral training." Male, age, and divorced come from IPUMS-CPS and represent the percentage of people in each occupation who are male or divorced, or the average age of people in an occupation. Monthly church is an occupational average from the GSS of an indicator variable for monthly (or more frequent) church attendance. Gun ownership is an occupational average from the GSS of an indicator for having a gun in the house. High associations are bolded. Detailed variable definitions are in the Appendix. 
Table 6

Models of Occupation-Level Workplace Misery

Panel A: All Occupations

\begin{tabular}{|c|c|c|c|c|c|c|c|c|c|c|c|c|}
\hline & \multicolumn{3}{|c|}{ Job dissatisfaction } & \multicolumn{3}{|c|}{ Unhappiness } & \multicolumn{3}{|c|}{$\ln ($ Mental health bad) } & \multicolumn{3}{|c|}{$\ln ($ Suicide rate $)$} \\
\hline & 1 & 2 & 3 & 4 & 5 & 6 & 7 & 8 & 9 & 10 & 11 & 12 \\
\hline Status & $-0.046 * * *$ & $-0.045 * * *$ & & $-0.041 * * *$ & $-0.041 * * *$ & & $-0.081 *$ & $-0.081 *$ & & $0.276^{* *}$ & $0.288^{*}$ & \\
\hline Blue collar & $-0.021 * * *$ & & & 0.008 & & & $-0.132 * * *$ & & & $0.856 * * *$ & & \\
\hline Repetitive & $0.015 * *$ & & & 0.007 & & & 0.052 & & & -0.165 & & \\
\hline Security & $-0.034 * * *$ & & & $-0.015^{* *}$ & & & 0.000 & & & -0.017 & & \\
\hline Income & & & $-0.012 * * *$ & & & $-0.012 * * *$ & & & $-0.053 * * *$ & & & $0.121 * * *$ \\
\hline Constant & $0.124 * * *$ & $0.124 * * *$ & $0.177 * * *$ & $1.123 * * *$ & $1.123 * * *$ & $1.187 * * *$ & $1.128 * * *$ & $1.127 * * *$ & $1.342 * * *$ & $-2.597 * * *$ & $-2.662 * * *$ & $-3.177 * * *$ \\
\hline $\mathrm{N}$ & 197 & 197 & 320 & 197 & 197 & 338 & 196 & 196 & 293 & 94 & 94 & 272 \\
\hline $\mathrm{R}^{2}$ & 0.322 & 0.182 & 0.093 & 0.282 & 0.239 & 0.111 & 0.064 & 0.016 & 0.038 & 0.367 & 0.036 & 0.045 \\
\hline
\end{tabular}

\begin{tabular}{|c|c|c|c|c|c|c|c|c|c|c|c|c|}
\hline \multirow[b]{3}{*}{ Accountants } & \multicolumn{3}{|c|}{ Model 1 Errors } & \multicolumn{3}{|c|}{ Model 4 Errors } & \multicolumn{3}{|c|}{ Model 7 Errors } & \multicolumn{3}{|c|}{ Model 10 Errors } \\
\hline & Job title & $y-\hat{y}$ & \%ile & Job title & $y-\hat{y}$ & \%ile & JobTitle & $y-\hat{y}$ & \%ile & Job title & $y-\hat{y}$ & \%ile \\
\hline & Accountants & -0.03 & $37 \%$ & Accountants & -0.03 & $31 \%$ & Accountants & -0.50 & $16 \%$ & Accountants & 0.75 & $85 \%$ \\
\hline \multirow{5}{*}{$\begin{array}{l}\text { Largest } 5 \\
\text { Errors } \\
\text { (more } \\
\text { misery } \\
\text { than } \\
\text { predicted) }\end{array}$} & $\begin{array}{l}\text { bill \& account } \\
\text { collectors }\end{array}$ & 0.40 & $99 \%$ & dishwashers & 0.23 & $99 \%$ & opticians, dispensing & 1.75 & $99 \%$ & $\begin{array}{l}\text { fishers and related } \\
\text { fishing workers }\end{array}$ & 6.66 & $99 \%$ \\
\hline & $\begin{array}{l}\text { hosts \& } \\
\text { hostesses }\end{array}$ & 0.32 & $99 \%$ & $\begin{array}{l}\text { bill and account } \\
\text { collectors }\end{array}$ & 0.23 & $99 \%$ & automotive body repairers & 1.21 & $99 \%$ & $\begin{array}{l}\text { artists and related } \\
\text { workers }\end{array}$ & 3.21 & $98 \%$ \\
\hline & roofers & 0.30 & $98 \%$ & $\begin{array}{l}\text { medical records } \\
\text { techs }\end{array}$ & 0.20 & $98 \%$ & drywall installers & 1.19 & $98 \%$ & $\begin{array}{l}\text { door-to-door sales and } \\
\text { street vendors }\end{array}$ & 2.31 & $97 \%$ \\
\hline & $\begin{array}{l}\text { computer } \\
\text { operators }\end{array}$ & 0.26 & $98 \%$ & $\begin{array}{l}\text { heavy vehicle } \\
\text { mechanics }\end{array}$ & 0.17 & $98 \%$ & painting workers & 1.13 & $98 \%$ & writers and authors & 2.29 & $96 \%$ \\
\hline & $\begin{array}{l}\text { tool and die } \\
\text { makers }\end{array}$ & 0.24 & $97 \%$ & refuse collectors & 0.15 & $97 \%$ & $\begin{array}{l}\text { supervisors of transportation } \\
\text { workers }\end{array}$ & 1.04 & $97 \%$ & massage therapists & 1.66 & $95 \%$ \\
\hline \multirow{5}{*}{$\begin{array}{l}\text { Smallest } 5 \\
\text { Errors } \\
\text { (less misery } \\
\text { than } \\
\text { predicted) }\end{array}$} & $\begin{array}{l}\text { interviewers, } \\
\text { except loan }\end{array}$ & -0.17 & $2 \%$ & $\begin{array}{l}\text { nonfarm animal } \\
\text { caretakers }\end{array}$ & -0.15 & $2 \%$ & $\begin{array}{l}\text { first-line supervisors of personal } \\
\text { service workers }\end{array}$ & -1.64 & $2 \%$ & personal care aides & -1.88 & $4 \%$ \\
\hline & $\begin{array}{l}\text { bellhops and } \\
\text { concierges }\end{array}$ & -0.18 & $2 \%$ & $\begin{array}{l}\text { molding machine } \\
\text { setters }\end{array}$ & -0.15 & $2 \%$ & sawing machine setters & -1.75 & $2 \%$ & $\begin{array}{l}\text { supervisors of } \\
\text { transportation workers }\end{array}$ & -2.10 & $3 \%$ \\
\hline & $\begin{array}{l}\text { molding } \\
\text { machine setters }\end{array}$ & -0.19 & $1 \%$ & $\begin{array}{l}\text { cleaners of } \\
\text { equipment }\end{array}$ & -0.17 & $1 \%$ & word processors and typists & -2.01 & $1 \%$ & $\begin{array}{l}\text { food preparation and } \\
\text { serving workers }\end{array}$ & -2.12 & $2 \%$ \\
\hline & mail clerks & -0.21 & $1 \%$ & $\begin{array}{l}\text { fishers and related } \\
\text { fishing workers }\end{array}$ & -0.18 & $1 \%$ & molding machine setters & -2.13 & $1 \%$ & $\begin{array}{l}\text { telecommunications } \\
\text { equip. installers }\end{array}$ & -2.29 & $1 \%$ \\
\hline & $\begin{array}{l}\text { cleaners of } \\
\text { equipment }\end{array}$ & -0.22 & $0 \%$ & $\begin{array}{l}\text { misc. entertainment } \\
\text { attendants }\end{array}$ & -0.19 & $0 \%$ & $\begin{array}{l}\text { cabinetmakers and bench } \\
\text { carpenters }\end{array}$ & -3.13 & $0 \%$ & $\begin{array}{l}\text { refuse and recyclable } \\
\text { material collectors }\end{array}$ & -2.67 & $0 \%$ \\
\hline
\end{tabular}


Table 6 (continued)

Models of Occupation-Level Workplace Misery

Panel B: Occupations Requiring "Some College”

\begin{tabular}{|c|c|c|c|c|c|c|c|c|c|c|c|c|}
\hline & \multicolumn{3}{|c|}{ Job dissatisfaction } & \multicolumn{3}{|c|}{ Unhappiness } & \multicolumn{3}{|c|}{$\ln ($ Mental health bad $)$} & \multicolumn{3}{|c|}{$\ln ($ Suicide rate $)$} \\
\hline & 1 & 2 & 3 & 4 & 5 & 6 & 7 & 8 & 9 & 10 & 11 & 12 \\
\hline Status & $-0.026 * *$ & $-0.023^{*}$ & & $-0.042 * * *$ & $-0.035 * * *$ & & -0.03 & -0.091 & & -0.021 & 0.285 & \\
\hline Blue collar & -0.001 & & & 0.013 & & & $-0.335 * * *$ & & & $1.412 * * *$ & & \\
\hline Repetitive & $0.016^{* *}$ & & & 0.005 & & & -0.005 & & & -0.121 & & \\
\hline Security & $-0.019 * * *$ & & & $-0.014 * *$ & & & -0.049 & & & -0.103 & & \\
\hline Income & & & $-0.008 * * *$ & & & $-0.007 * * *$ & & & $-0.039 *$ & & & 0.069 \\
\hline Constant & $0.104 * * *$ & $0.098 * * *$ & $0.148 * * *$ & $1.121 * * *$ & $1.113 * * *$ & $1.137 * * *$ & $0.977 * * *$ & $1.097 * * *$ & $1.217 * * *$ & $-2.204 * * *$ & $-2.720 * * *$ & $-2.961 * * *$ \\
\hline $\mathrm{N}$ & 78 & 78 & 146 & 78 & 78 & 154 & 77 & 77 & 134 & 30 & 30 & 103 \\
\hline $\mathrm{R}^{2}$ & 0.255 & 0.044 & 0.073 & 0.208 & 0.103 & 0.045 & 0.117 & 0.008 & 0.025 & 0.301 & 0.018 & 0.026 \\
\hline
\end{tabular}

\begin{tabular}{|c|c|c|c|c|c|c|c|c|c|c|c|c|}
\hline & \multicolumn{3}{|c|}{ Model 1 Errors } & \multicolumn{3}{|c|}{ Model 4 Errors } & \multicolumn{3}{|c|}{ Model 7 Errors } & \multicolumn{3}{|c|}{ Model 10 Errors } \\
\hline & Job title & $y-\hat{y}$ & \%ile & Job title & $y-\hat{y}$ & \%ile & JobTitle & $y-\hat{y}$ & \%ile & Job title & $y-\hat{y}$ & \%ile \\
\hline accountants & accountants & -0.02 & $37 \%$ & accountants & -0.02 & $31 \%$ & accountants & -0.47 & $17 \%$ & accountants & 0.98 & $83 \%$ \\
\hline \multirow{7}{*}{$\begin{array}{l}\text { Largest } 5 \\
\text { Errors } \\
\text { (more misery } \\
\text { than } \\
\text { predicted) }\end{array}$} & lawyers & 0.14 & $99 \%$ & transportation managers & 0.14 & $99 \%$ & artists and related & 1.08 & $99 \%$ & artists and related & 2.88 & $97 \%$ \\
\hline & purchasing agents & 0.11 & $97 \%$ & artists and related & 0.13 & $97 \%$ & pharmacists & 0.96 & $97 \%$ & writers and authors & 2.31 & $93 \%$ \\
\hline & tax preparers & 0.10 & $96 \%$ & lawyers & 0.08 & $96 \%$ & other education workers & 0.90 & $96 \%$ & clergy & 1.34 & $90 \%$ \\
\hline & public relations & 0.10 & $95 \%$ & construction managers & 0.08 & $95 \%$ & psychologists & 0.85 & $95 \%$ & private detectives and & 1.30 & $87 \%$ \\
\hline & specialists & & & & & & & & & investigators & & \\
\hline & $\begin{array}{l}\text { customer service } \\
\text { reps }\end{array}$ & 0.10 & $94 \%$ & $\begin{array}{l}\text { first-line supervisors of } \\
\text { personal service workers }\end{array}$ & 0.07 & $94 \%$ & social workers & 0.71 & $94 \%$ & accountants & 0.98 & $83 \%$ \\
\hline & librarians & -0.07 & $5 \%$ & $\begin{array}{l}\text { operations research } \\
\text { analysts }\end{array}$ & -0.08 & $5 \%$ & $\begin{array}{l}\text { human resources } \\
\text { assistants }\end{array}$ & -0.89 & $5 \%$ & $\begin{array}{l}\text { recreation and fitness } \\
\text { workers }\end{array}$ & -0.96 & $13 \%$ \\
\hline \multirow{4}{*}{$\begin{array}{l}\text { Smallest } 5 \\
\text { Errors } \\
\text { (less misery } \\
\text { than } \\
\text { predicted) }\end{array}$} & $\begin{array}{l}\text { purchasing } \\
\text { managers }\end{array}$ & -0.07 & $4 \%$ & financial analysts & -0.08 & $4 \%$ & drafters & -0.91 & $4 \%$ & purchasing agents & -1.15 & $10 \%$ \\
\hline & $\begin{array}{l}\text { other education } \\
\text { workers }\end{array}$ & -0.07 & $3 \%$ & $\begin{array}{l}\text { financial services sales } \\
\text { agents }\end{array}$ & -0.09 & $3 \%$ & engineers, all other & -0.95 & $3 \%$ & drafters & -1.46 & $7 \%$ \\
\hline & $\begin{array}{l}\text { insurance } \\
\text { underwriters }\end{array}$ & -0.09 & $1 \%$ & $\begin{array}{l}\text { private detectives and } \\
\text { investigators }\end{array}$ & -0.10 & $1 \%$ & physical therapists & -1.15 & $1 \%$ & $\begin{array}{l}\text { operations research } \\
\text { analysts }\end{array}$ & -1.55 & $3 \%$ \\
\hline & $\begin{array}{l}\text { private detectives } \\
\text { and investigators }\end{array}$ & -0.09 & $0 \%$ & detectives & -0.11 & $0 \%$ & $\begin{array}{l}\text { first-line supervisors of } \\
\text { personal service workers }\end{array}$ & -1.61 & $0 \%$ & detectives & -1.70 & $0 \%$ \\
\hline
\end{tabular}

We produce this table using data from O*NET, GSS, OES, IPUMS-CPS, IPUMS-ATUS-X, CDC, and OES. We estimate models using OLS. Job dissatisfaction and unhappiness are occupation averages of indicator variables from the GSS for low job satisfaction and general unhappiness. Mental health bad is an

occupation average of the days during the last month that GSS respondents reported having poor mental health. Suicide rate is an estimate of the suicide rate in 
an occupation per 1,000 occupation members using CDC and OES data. Status, blue collar, repetitive, and security are factors calculated from the model 2 independent variables. Table 5 describes these factors and Table 4 describes the input variables we used to create them. Income is in tens of thousands of 2016 dollars from the OES. The top of each panel shows coefficients from estimations of models explaining variation in workplace misery. The bottom of each panel lists regression errors and their percentile relative to other errors for accounting and for the five occupations with the largest and smallest regression errors in models $1,4,7$, and 10. Stars represent statistically significant two-tailed coefficients at the p < $0.01(* * *), 0.05(* *)$, and $0.10(*)$ levels. Detailed variable definitions are in the Appendix. 
Table 7

Descriptive Statistics for Model 3 Variables

Panel A: People Working 10+ Hours per Week

\begin{tabular}{|c|c|c|c|c|c|c|c|c|c|}
\hline & \multicolumn{6}{|c|}{ Non-accountants } & \multicolumn{3}{|c|}{ Accountants } \\
\hline & $\mathrm{N}$ & mean & $\mathrm{p} 50$ & $\min$ & $\max$ & sd & $\mathrm{N}$ & mean & Diff \\
\hline Job dissatisfaction & 3,322 & 0.07 & 0.00 & 0.00 & 1.00 & 0.26 & 39 & 0.08 & 0.01 \\
\hline Depression & 3,316 & 5.87 & 5.00 & 0.00 & 28.00 & 4.45 & 39 & 5.08 & -0.78 \\
\hline Stress scale & 3,314 & 4.69 & 4.00 & 0.00 & 16.00 & 2.84 & 39 & 4.21 & -0.48 \\
\hline Suicidal thoughts & 3,322 & 0.06 & 0.00 & 0.00 & 1.00 & 0.24 & 39 & 0.02 & $-0.04 *$ \\
\hline Accountants & 3,322 & 0.00 & 0.00 & 0.00 & 0.00 & 0.00 & 39 & 1.00 & 1.00 \\
\hline Income & 3,167 & 4.10 & 3.36 & 0.00 & 87.40 & 4.30 & 37 & 5.15 & $1.05 * * *$ \\
\hline Prestige & 3,320 & 4.99 & 5.00 & 1.00 & 10.00 & 1.63 & 39 & 5.52 & $0.53 * *$ \\
\hline Hours worked & 3,321 & 41.62 & 40.00 & 10.00 & 120.00 & 11.42 & 39 & 42.34 & 0.72 \\
\hline Long hours & 3,322 & 0.09 & 0.00 & 0.00 & 1.00 & 0.28 & 39 & 0.00 & $-0.09 * * *$ \\
\hline Irregular hours & 3,322 & 0.18 & 0.00 & 0.00 & 1.00 & 0.39 & 39 & 0.02 & $-0.16 * * *$ \\
\hline Free to make decisions & 3,322 & 0.69 & 1.00 & 0.00 & 1.00 & 0.46 & 39 & 0.81 & 0.11 \\
\hline Work repetitive & 3,322 & 0.62 & 1.00 & 0.00 & 1.00 & 0.49 & 39 & 0.48 & -0.14 \\
\hline High school graduate & 3,322 & 0.27 & 0.00 & 0.00 & 1.00 & 0.44 & 39 & 0.02 & $-0.25 * * *$ \\
\hline Bachelor's degree & 3,322 & 0.22 & 0.00 & 0.00 & 1.00 & 0.42 & 39 & 0.59 & $0.37 * * *$ \\
\hline Master's degree & 3,322 & 0.06 & 0.00 & 0.00 & 1.00 & 0.24 & 39 & 0.13 & 0.07 \\
\hline Doctorate & 3,322 & 0.01 & 0.00 & 0.00 & 1.00 & 0.08 & 39 & 0.00 & $-0.01 * * *$ \\
\hline Professional degree & 3,322 & 0.01 & 0.00 & 0.00 & 1.00 & 0.12 & 39 & 0.00 & $-0.01 * * *$ \\
\hline Female & 3,321 & 0.46 & 0.00 & 0.00 & 1.00 & 0.50 & 39 & 0.67 & $0.21 * *$ \\
\hline Childhood income & 2,554 & 0.01 & 0.01 & 0.00 & 0.15 & 0.01 & 28 & 0.01 & 0.00 \\
\hline Family interferes work & 3,322 & 0.14 & 0.00 & 0.00 & 1.00 & 0.35 & 39 & 0.07 & $-0.07 *$ \\
\hline Work interferes family & 3,322 & 0.45 & 0.00 & 0.00 & 1.00 & 0.50 & 39 & 0.29 & $-0.16^{* *}$ \\
\hline Daily prayer & 3,322 & 0.37 & 0.00 & 0.00 & 1.00 & 0.48 & 39 & 0.50 & 0.12 \\
\hline Weekly church & 3,322 & 0.16 & 0.00 & 0.00 & 1.00 & 0.36 & 39 & 0.16 & 0.01 \\
\hline Close friends & 3,322 & 3.14 & 3.00 & 0.00 & 5.00 & 1.04 & 39 & 3.01 & -0.13 \\
\hline Excessive drinking & 3,322 & 0.53 & 1.00 & 0.00 & 1.00 & 0.50 & 39 & 0.52 & -0.01 \\
\hline Marijuana & 3,322 & 0.24 & 0.00 & 0.00 & 1.00 & 0.43 & 39 & 0.17 & -0.08 \\
\hline Drugs & 3,322 & 0.12 & 0.00 & 0.00 & 1.00 & 0.32 & 39 & 0.02 & $-0.10 * * *$ \\
\hline Neurotic personality & 3,322 & -0.03 & -0.11 & -1.75 & 2.61 & 0.82 & 39 & -0.09 & -0.06 \\
\hline Extraverted personality & 3,322 & 0.03 & 0.09 & -2.48 & 2.08 & 0.84 & 39 & -0.24 & $-0.27 * *$ \\
\hline Conscientious personality & 3,322 & -0.03 & 0.05 & -2.88 & 3.21 & 0.81 & 39 & 0.27 & $0.31 * * *$ \\
\hline Open personality & 3,322 & 0.01 & -0.06 & -2.58 & 4.44 & 0.81 & 39 & -0.04 & -0.04 \\
\hline Agreeable personality & 3,322 & -0.04 & 0.21 & -3.81 & 1.84 & 0.84 & 39 & 0.03 & 0.07 \\
\hline Childhood depression & 3,310 & 10.68 & 9.00 & 0.00 & 48.00 & 7.20 & 39 & 8.12 & $-2.56 * *$ \\
\hline Childhood suicidal thoughts & 3,322 & 0.13 & 0.00 & 0.00 & 1.00 & 0.34 & 39 & 0.10 & -0.03 \\
\hline Childhood suicide attempts & 3,322 & 0.04 & 0.00 & 0.00 & 1.00 & 0.19 & 39 & 0.02 & -0.02 \\
\hline Childhood fam/friend suicide & 3,322 & 0.04 & 0.00 & 0.00 & 1.00 & 0.20 & 39 & 0.03 & -0.01 \\
\hline Childhood friends care & 3,322 & 0.85 & 1.00 & 0.00 & 1.00 & 0.36 & 39 & 0.91 & 0.06 \\
\hline Childhood parents care & 3,322 & 0.96 & 1.00 & 0.00 & 1.00 & 0.20 & 39 & 0.98 & 0.02 \\
\hline Childhood physical abuse & 3,322 & 0.51 & 0.00 & 0.00 & 5.00 & 1.27 & 39 & 0.15 & $-0.35 * * *$ \\
\hline Childhood sexual abuse & 3,322 & 0.11 & 0.00 & 0.00 & 5.00 & 0.61 & 39 & 0.00 & $-0.11 * * *$ \\
\hline
\end{tabular}


Table 7 (continued)

Descriptive Statistics for Model 3 Variables

Panel B: People Working 30+ Hours per Week and with Bachelor's or Higher Degree

\begin{tabular}{|c|c|c|c|c|c|c|c|c|c|}
\hline & \multicolumn{6}{|c|}{ Non-accountants } & \multicolumn{3}{|c|}{ Accountants } \\
\hline & $\mathrm{N}$ & mean & p50 & $\min$ & $\max$ & $\mathrm{sd}$ & $\mathrm{N}$ & mean & Diff \\
\hline Job dissatisfaction & 1,000 & 0.07 & 0.00 & 0.00 & 1.00 & 0.26 & 28 & 0.11 & 0.04 \\
\hline Depression & 999 & 4.94 & 4.00 & 0.00 & 23.00 & 3.96 & 28 & 5.18 & 0.24 \\
\hline Stress scale & 994 & 3.93 & 4.00 & 0.00 & 13.00 & 2.59 & 28 & 4.03 & 0.09 \\
\hline Suicidal thoughts & 1,000 & 0.05 & 0.00 & 0.00 & 1.00 & 0.22 & 28 & 0.00 & $-0.05 * * *$ \\
\hline Accountants & 1,000 & 0.00 & 0.00 & 0.00 & 0.00 & 0.00 & 28 & 1.00 & 1.00 \\
\hline Income & 980 & 5.64 & 4.47 & 0.00 & 87.40 & 5.80 & 27 & 5.52 & -0.12 \\
\hline Prestige & 1,000 & 5.82 & 6.00 & 2.00 & 10.00 & 1.53 & 28 & 5.89 & 0.08 \\
\hline Hours worked & 1,000 & 44.30 & 40.00 & 30.00 & 90.00 & 8.59 & 28 & 42.93 & -1.36 \\
\hline Long hours & 1,000 & 0.09 & 0.00 & 0.00 & 1.00 & 0.29 & 28 & 0.00 & $-0.09 * * *$ \\
\hline Irregular hours & 1,000 & 0.16 & 0.00 & 0.00 & 1.00 & 0.36 & 28 & 0.03 & $-0.12 * * *$ \\
\hline Free to make decisions & 1,000 & 0.78 & 1.00 & 0.00 & 1.00 & 0.41 & 28 & 0.80 & 0.02 \\
\hline Work repetitive & 1,000 & 0.44 & 0.00 & 0.00 & 1.00 & 0.50 & 28 & 0.42 & -0.02 \\
\hline High school graduate & 1,000 & 0.00 & 0.00 & 0.00 & 0.00 & 0.00 & 28 & 0.00 & 0.00 \\
\hline Bachelor's degree & 1,000 & 0.73 & 1.00 & 0.00 & 1.00 & 0.44 & 28 & 0.82 & 0.09 \\
\hline Master's degree & 1,000 & 0.20 & 0.00 & 0.00 & 1.00 & 0.40 & 28 & 0.18 & -0.02 \\
\hline Doctorate & 1,000 & 0.02 & 0.00 & 0.00 & 1.00 & 0.15 & 28 & 0.00 & $-0.02 * * *$ \\
\hline Professional degree & 1,000 & 0.05 & 0.00 & 0.00 & 1.00 & 0.21 & 28 & 0.00 & $-0.05 * * *$ \\
\hline Female & 999 & 0.52 & 1.00 & 0.00 & 1.00 & 0.50 & 28 & 0.64 & 0.12 \\
\hline Childhood income & 786 & 0.01 & 0.01 & 0.00 & 0.15 & 0.01 & 22 & 0.01 & 0.00 \\
\hline Family interferes work & 1,000 & 0.12 & 0.00 & 0.00 & 1.00 & 0.32 & 28 & 0.07 & -0.04 \\
\hline Work interferes family & 1,000 & 0.39 & 0.00 & 0.00 & 1.00 & 0.49 & 28 & 0.30 & -0.09 \\
\hline Daily prayer & 1,000 & 0.40 & 0.00 & 0.00 & 1.00 & 0.49 & 28 & 0.41 & 0.01 \\
\hline Weekly church & 1,000 & 0.21 & 0.00 & 0.00 & 1.00 & 0.41 & 28 & 0.23 & 0.02 \\
\hline Close friends & 1,000 & 3.43 & 3.00 & 0.00 & 5.00 & 1.04 & 28 & 2.98 & $-0.45 * * *$ \\
\hline Excessive drinking & 1,000 & 0.57 & 1.00 & 0.00 & 1.00 & 0.50 & 28 & 0.51 & -0.06 \\
\hline Marijuana & 1,000 & 0.20 & 0.00 & 0.00 & 1.00 & 0.40 & 28 & 0.09 & $-0.12 * *$ \\
\hline Drugs & 1,000 & 0.09 & 0.00 & 0.00 & 1.00 & 0.28 & 28 & 0.00 & $-0.09 * * *$ \\
\hline Neurotic personality & 1,000 & -0.21 & -0.45 & -1.75 & 2.61 & 0.78 & 28 & -0.05 & 0.16 \\
\hline Extraverted personality & 1,000 & 0.06 & 0.15 & -2.48 & 1.83 & 0.84 & 28 & -0.27 & $-0.32 * *$ \\
\hline Conscientious personality & 1,000 & 0.04 & 0.16 & -2.77 & 1.58 & 0.82 & 28 & 0.34 & $0.30 * *$ \\
\hline Open personality & 1,000 & 0.23 & 0.45 & -2.45 & 4.44 & 0.74 & 28 & 0.03 & -0.20 \\
\hline Agreeable personality & 1,000 & 0.21 & 0.24 & -2.77 & 1.69 & 0.72 & 28 & -0.03 & $-0.24 * *$ \\
\hline Childhood depression & 997 & 8.82 & 8.00 & 0.00 & 46.00 & 6.21 & 28 & 7.47 & -1.36 \\
\hline Childhood suicidal thoughts & 1,000 & 0.10 & 0.00 & 0.00 & 1.00 & 0.31 & 28 & 0.04 & -0.06 \\
\hline Childhood suicide attempts & 1,000 & 0.02 & 0.00 & 0.00 & 1.00 & 0.15 & 28 & 0.00 & $-0.02 * * *$ \\
\hline Childhood fam/friend suicide & 1,000 & 0.03 & 0.00 & 0.00 & 1.00 & 0.17 & 28 & 0.04 & 0.01 \\
\hline Childhood friends care & 1,000 & 0.90 & 1.00 & 0.00 & 1.00 & 0.30 & 28 & 0.90 & 0.01 \\
\hline Childhood parents care & 1,000 & 0.97 & 1.00 & 0.00 & 1.00 & 0.16 & 28 & 1.00 & $0.03 * * *$ \\
\hline Childhood physical abuse & 1,000 & 0.36 & 0.00 & 0.00 & 5.00 & 1.05 & 28 & 0.21 & -0.14 \\
\hline Childhood sexual abuse & 1,000 & 0.07 & 0.00 & 0.00 & 5.00 & 0.49 & 28 & 0.00 & $-0.07 * * *$ \\
\hline
\end{tabular}

Data summarized in this table come from Add health. Job dissatisfaction is an indicator for people who are dissatisfied with their job. Depression is a scale measure of depression constructed from 10 questions from the Center for Epidemiologic Studies Depression Scale (CES-D). Stress scale is a scale measure of stress constructed from four questions from the Cohen Perceived Stress Scale. Suicidal thoughts is an indicator for people who report that they have thought seriously about committing suicide during the last 12 months. Accountants is an indicator variable for accountants. Income is personal income in 2016 dollars. Prestige is a score from 1 to 10 representing where a person feels they sit on a ladder representing "where people stand in the United States" in terms of the most money, education, and respected jobs. Hours worked is the number of hours typically worked in a week. Long hours 
is an indicator for people who work more than 55 hours a week. Irregular hours is an indicator for people who report working rotating or irregular shifts. Free to make decisions is an indicator variable for people who feel that they are free to make decisions at work. Work repetitive is an indicator for people who feel that their job is repetitive. High school graduate, bachelor's degree, master's degree, doctorate, and professional degree are indicator variables for respondents' highest degrees. Female is an indicator variable for women. Childhood income is an estimate of family income when the respondent was an adolescent. Family interferes work and work interferes family are indicator variables for people who feel that work and family interfere with one another. Daily prayer is an indicator variable for people who pray at least daily. Weekly church is an indicator variable for people who attend church at least weekly. Close friends is a measure of the number of close friends a person has. Excessive drinking is an indicator variable for people whose drinking behavior meets the CDC's definition of excessive drinking.

Marijuana is an indicator variable for marijuana users. Drugs is an indicator for users of other illegal drugs.

Neurotic, extraverted, conscientious, open, and agreeable personality are the "big-5" personality traits. Childhood depression, suicidal thoughts, and suicide attempts are indicator variables for people who had these experiences during childhood. Childhood fam/friend suicide is an indicator for people who, as children, were close to a person who committed suicide. Childhood friends care, and parents care are indicator variables for people who felt as adolescents that their friends or parents cared about them. Childhood physical abuse, and sexual abuse are indicators for people who, as adults, report that they were abused as children. Data on the left are for non-accountants while data on the right are for only accountants. The column labelled "Diff" is the difference between the mean value for non-accountants and accountants. Stars in this column represent statistically significant two-tailed differences at the $\mathrm{p}<0.01(* *), 0.05(* *)$, and $0.10(*)$ levels. Detailed variable definitions are in the Appendix. 
Table 8

Models of Workplace Misery in Add Health

Panel A: People Working 10+ Hours per Week

\begin{tabular}{|c|c|c|c|c|c|c|c|c|}
\hline & \multicolumn{2}{|c|}{ Job dissatisfaction } & \multicolumn{2}{|c|}{ Depression } & \multicolumn{2}{|c|}{ Stress scale } & \multicolumn{2}{|c|}{ Suicidal thoughts } \\
\hline & 1 & 2 & 3 & 4 & 5 & 6 & 7 & 8 \\
\hline$\overline{\text { Accountants }}$ & 0.004 & -0.019 & 0.306 & -0.572 & -0.023 & 0.306 & -0.010 & -0.086 \\
\hline Income & $0.003 *$ & 0.002 & 0.001 & -0.003 & 0.005 & 0.002 & 0.001 & 0.000 \\
\hline Prestige & $-0.023 * * *$ & $-0.023 * * *$ & $-0.420 * * *$ & $-0.399 * * *$ & $-0.388 * * *$ & $-0.400 * * *$ & $-0.017 * * *$ & $-0.014 * * *$ \\
\hline Hours worked & 0.000 & 0.000 & -0.005 & -0.004 & $-0.016 * *$ & -0.014 & 0.000 & 0.000 \\
\hline Long hours & -0.027 & -0.015 & 0.377 & 0.394 & 0.082 & 0.120 & 0.000 & 0.019 \\
\hline Irregular hours & -0.009 & -0.015 & -0.186 & 0.020 & 0.234 & 0.278 & -0.012 & -0.008 \\
\hline Free to make decisions & $-0.076 * * *$ & $-0.071 * * *$ & $-0.489 * *$ & $-0.451 * *$ & $-0.311 * *$ & $-0.328 * *$ & -0.005 & -0.013 \\
\hline Work repetitive & 0.016 & 0.005 & -0.016 & 0.169 & 0.014 & 0.001 & 0.009 & 0.014 \\
\hline High school graduate & 0.017 & 0.015 & 0.013 & 0.180 & -0.213 & -0.189 & -0.008 & -0.010 \\
\hline Bachelor's degree & $0.064 * * *$ & $0.070 * * *$ & 0.243 & 0.284 & 0.016 & 0.019 & 0.022 & $0.041 * * *$ \\
\hline Master's degree & $0.074 * * *$ & $0.090 * * *$ & 0.253 & 0.119 & $-0.357 *$ & -0.245 & 0.018 & 0.024 \\
\hline Doctorate & 0.004 & -0.031 & -0.264 & -0.345 & -0.562 & $-1.045^{* *}$ & 0.002 & 0.069 \\
\hline Professional degree & $0.103 * *$ & 0.094 & $2.053 * * *$ & $2.366 * *$ & 0.419 & $0.777^{*}$ & $0.133 * *$ & $0.169 * *$ \\
\hline Female & 0.003 & -0.009 & -0.191 & -0.354 & 0.009 & -0.067 & -0.011 & -0.015 \\
\hline Childhood income & $-1.075^{*}$ & $-1.976 * * *$ & 7.142 & 2.877 & -2.835 & -3.222 & 0.844 & -0.297 \\
\hline Family i & 0.023 & $0.031 *$ & $0.996 * * *$ & $1.065 * * *$ & $0.588 * * *$ & $0.753 * * *$ & 0.013 & 0.021 \\
\hline Work interferes family & 0.015 & 0.014 & $0.476 * * *$ & $0.699 * * *$ & $0.294 * * *$ & $0.389 * * *$ & 0.002 & 0.016 \\
\hline Daily $p$ & -0.011 & $-0.024 *$ & 0.286 & 0.138 & 0.137 & -0.009 & -0.012 & -0.012 \\
\hline $\mathrm{We}$ & & & & & & 0.092 & & 0.014 \\
\hline Close friends & 0.000 & 0.006 & -0.102 & -0.114 & -0.086 & $-0.121 *$ & $-0.010 *$ & $-0.013 * *$ \\
\hline sive drinking & -0.002 & 0.001 & 0.274 & $0.350 *$ & $0.346 * * *$ & $0.333 * *$ & 0.008 & 0.017 \\
\hline Marijua & -0.003 & -0.007 & 0.282 & 0.279 & 0.003 & -0.016 & 0.008 & 0.017 \\
\hline Drugs & 0.025 & 0.019 & 0.389 & 0.345 & $0.324 * *$ & $0.314^{*}$ & $0.050 * *$ & $0.058 * * *$ \\
\hline Neurot & 0.012 & $0.019 * *$ & $2.089 * * *$ & $2.184 *$ & $1.066 * * *$ & $1.090 * * *$ & $0.044 * * *$ & $0.042 * * *$ \\
\hline erted personality & -0.007 & -0.008 & $-0.612 * * *$ & $-0.605 * * *$ & $-0.299 * * *$ & $-0.245 * * *$ & $-0.018 * *$ & $-0.020 * *$ \\
\hline Conscientious personality & $-0.012 *$ & -0.006 & $-0.467 * * *$ & $-0.585 * * *$ & $-0.334 * * *$ & $-0.395 * * *$ & -0.005 & -0.009 \\
\hline Open personality & $0.028 * * *$ & $0.021 * * *$ & 0.137 & 0.131 & 0.092 & $0.135^{*}$ & 0.010 & 0.006 \\
\hline onality & $-0.018^{*}$ & -0.005 & 0.099 & 0.201 & $0.153 *$ & $0.164 *$ & 0.015 & $0.017 * *$ \\
\hline ood depression & 0.001 & 0.000 & $0.110 * *$ & $0.105 * * *$ & $0.038 * * *$ & $0.033 * * *$ & 0.000 & 0.000 \\
\hline cidal thoughts & 0.006 & -0.015 & -0.056 & -0.314 & -0.173 & -0.264 & $0.049 * *$ & $0.045 * *$ \\
\hline cide attempts & 0.031 & & & $1.132 * *$ & $0.581 *$ & $0.760 * * *$ & 0.060 & $0.082 *$ \\
\hline $\mathrm{m} /$ friend suicide & -0.039 & $-0.058 * *$ & 0.320 & 0.397 & 0.260 & 0.318 & 0.004 & -0.008 \\
\hline Childhood friends care & -0.017 & -0.023 & 0.231 & 0.340 & -0.150 & -0.065 & 0.006 & $0.026 *$ \\
\hline Childhood parents care & 0.006 & 0.021 & -0.407 & -0.310 & -0.204 & -0.149 & -0.056 & -0.045 \\
\hline Child. physical abuse & 0.007 & 0.002 & $0.195 * * *$ & $0.195 * * *$ & $0.122 * * *$ & $0.128 * *$ & 0.008 & 0.005 \\
\hline Childhood sexual abuse & 0.017 & 0.014 & 0.004 & 0.010 & -0.117 & -0.119 & $0.054 * * *$ & $0.048 * * *$ \\
\hline Constant & $0.180 * * *$ & $0.198 * *$ & $6.931 * * *$ & $7.536 * * *$ & $7.167 * * *$ & $6.928 * * *$ & $0.177 * * *$ & $0.228 * * *$ \\
\hline $\mathrm{N}$ & 2,460 & 2,448 & 2,457 & 2,445 & 2,457 & 2,445 & 2,460 & 2,448 \\
\hline $\mathrm{R}^{2}$ & 0.074 & 0.272 & 0.372 & 0.499 & 0.301 & 0.452 & 0.118 & 0.363 \\
\hline Occupation FE & No & Yes & No & Yes & No & Yes & No & Yes \\
\hline
\end{tabular}


Table 8 (continued)

Models of Workplace Misery in Add Health

Panel B: People Working 30+ Hours per Week and with Bachelor's or Higher Degree

\begin{tabular}{|c|c|c|c|c|c|c|c|c|}
\hline & \multicolumn{2}{|c|}{ Job dissatisfaction } & \multicolumn{2}{|c|}{ Depression } & \multicolumn{2}{|c|}{ Stress scale } & \multicolumn{2}{|c|}{ Suicidal thoughts } \\
\hline & 1 & 2 & 3 & 4 & 5 & 6 & 7 & 8 \\
\hline$\overline{\text { Accountants }}$ & 0.012 & 0.068 & 0.420 & 0.587 & 0.167 & 0.679 & -0.025 & -0.037 \\
\hline Income & 0.001 & -0.004 & 0.018 & -0.004 & 0.012 & -0.024 & 0.002 & 0.003 \\
\hline Prestige & $-0.027 * * *$ & $-0.017 * *$ & $-0.319 * * *$ & $-0.203^{*}$ & $-0.284 * * *$ & $-0.319 * * *$ & $-0.016 * * *$ & $-0.011 *$ \\
\hline Hours worked & -0.001 & -0.002 & $-0.045^{*}$ & -0.013 & $-0.046 * * *$ & -0.023 & -0.002 & 0.000 \\
\hline Long hours & 0.010 & 0.046 & $1.632 * *$ & $1.138 *$ & $1.125^{* *}$ & $1.060 * *$ & $0.067 *$ & 0.055 \\
\hline Irregular hours & -0.025 & 0.001 & -0.277 & $-0.713 *$ & -0.148 & 0.126 & 0.014 & 0.032 \\
\hline Free to make decisions & $-0.096 * * *$ & $-0.060 * *$ & $-0.533^{*}$ & -0.157 & $-0.569 * *$ & -0.384 & -0.029 & -0.019 \\
\hline Work repetitive & 0.006 & -0.001 & 0.043 & 0.034 & 0.108 & 0.044 & -0.004 & -0.015 \\
\hline High school grad. & & & & & & & & \\
\hline Bachelor's degree & 0.038 & -0.008 & $-1.582 * * *$ & $-1.944 * *$ & -0.289 & $-0.827 *$ & 0.019 & -0.133 \\
\hline Master's degree & 0.056 & 0.009 & $-1.685^{* * *}$ & $-2.288 * * *$ & -0.676 & $-1.069 * *$ & 0.016 & -0.143 \\
\hline Doctorate & 0.000 & -0.101 & $-2.286 * *$ & $-2.604 * * *$ & -0.957 & $-1.658 * * *$ & 0.000 & -0.128 \\
\hline Professional degree & $0.091 * *$ & 0.000 & 0.000 & 0.000 & 0.000 & 0.000 & $0.125^{* *}$ & 0.000 \\
\hline Female & -0.019 & -0.037 & -0.098 & -0.207 & -0.206 & -0.223 & -0.009 & -0.017 \\
\hline Childhood income & -0.325 & $-1.815^{*}$ & -0.873 & -8.588 & -5.233 & $-13.432 *$ & $-1.064 * *$ & $-1.452 * * *$ \\
\hline Family interferes work & 0.039 & -0.005 & $1.040^{* *}$ & $1.318 * * *$ & 0.445 & $1.041 * * *$ & -0.011 & 0.002 \\
\hline Work interferes family & 0.033 & 0.041 & 0.213 & $0.737 * * *$ & 0.083 & 0.130 & -0.022 & -0.020 \\
\hline Daily prayer & -0.016 & $-0.050^{*}$ & -0.035 & -0.189 & 0.166 & -0.114 & -0.023 & -0.011 \\
\hline Weekly church & -0.013 & 0.021 & 0.314 & $0.827 * *$ & $0.365^{*}$ & $0.542 * *$ & -0.012 & 0.001 \\
\hline Close friends & -0.002 & -0.003 & -0.039 & -0.057 & -0.034 & -0.064 & -0.002 & -0.010 \\
\hline Excessive drinking & -0.012 & 0.006 & 0.408 & 0.482 & $0.330^{*}$ & 0.315 & -0.023 & 0.020 \\
\hline Marijuana & 0.023 & 0.008 & 0.073 & -0.407 & -0.055 & 0.005 & 0.024 & 0.003 \\
\hline Drugs & 0.003 & -0.018 & 0.795 & $1.140 * *$ & $0.995^{* *}$ & $1.216^{* * *}$ & $0.091 *$ & $0.112 *$ \\
\hline Neurotic personality & 0.027 & $0.038 * *$ & $2.026 * * *$ & $1.958 * * *$ & $1.151 * * *$ & $1.057 * * *$ & $0.030 * *$ & 0.016 \\
\hline Extraverted personality & 0.000 & 0.005 & $-0.541 * * *$ & $-0.602 * * *$ & $-0.337 * * *$ & $-0.296 * * *$ & $-0.028 * * *$ & $-0.032 * *$ \\
\hline Conscientious personality & $0.019 *$ & 0.020 & $-0.714 * * *$ & $-0.778 * * *$ & $-0.457 * * *$ & $-0.533 * * *$ & -0.007 & -0.007 \\
\hline Open personality & 0.024 & $0.027 *$ & -0.068 & 0.078 & -0.056 & 0.034 & -0.010 & -0.019 \\
\hline Agreeable personality & -0.024 & 0.022 & -0.084 & -0.219 & -0.011 & -0.032 & 0.015 & 0.019 \\
\hline Child. depression & 0.001 & 0.003 & $0.112 * * *$ & $0.086 * * *$ & $0.044 * * *$ & $0.037 * *$ & 0.002 & 0.002 \\
\hline Child. suicidal tho & 0.045 & 0.019 & 0.252 & 0.879 & -0.156 & 0.202 & 0.012 & -0.004 \\
\hline Child. suicide attempts & 0.061 & 0.021 & 1.216 & 0.090 & 1.043 & 0.565 & $0.274 * *$ & 0.159 \\
\hline Child. fam/friend suicide & -0.059 & -0.025 & 0.554 & 0.353 & -0.042 & -0.251 & -0.018 & 0.025 \\
\hline Childhood friends care & -0.043 & -0.061 & -0.343 & -0.908 & -0.041 & -0.341 & -0.023 & -0.030 \\
\hline Childhood parents care & $0.093 * *$ & 0.046 & -0.364 & 0.292 & -0.353 & -0.107 & -0.127 & -0.031 \\
\hline Child. physical abuse & 0.011 & 0.005 & $0.339^{* *}$ & $0.355^{* *}$ & 0.112 & 0.123 & 0.002 & 0.000 \\
\hline Childhood sexual abuse & -0.010 & -0.008 & 0.142 & 0.189 & 0.025 & -0.160 & $0.044 *$ & 0.027 \\
\hline Constant & $0.271 * *$ & $0.307 * *$ & $10.105^{* * *}$ & $8.086^{* * *}$ & $8.311 * * *$ & $7.915^{* * *}$ & $0.385^{* *}$ & $0.359 * *$ \\
\hline $\mathrm{N}$ & 790 & 786 & 789 & 785 & 787 & 783 & 790 & 786 \\
\hline $\mathrm{R}^{2}$ & 0.103 & 0.445 & 0.443 & 0.624 & 0.352 & 0.557 & 0.179 & 0.518 \\
\hline Occupation FE & No & Yes & No & Yes & No & Yes & No & Yes \\
\hline
\end{tabular}

Data summarized in this table come from Add health. We estimate models using OLS. Dependent variables are job dissatisfaction, an indicator for people who are dissatisfied with their job, depression, a scale measure of depression constructed from 10 questions from the Center for Epidemiologic Studies Depression Scale (CES-D), stress scale, a scale measure of stress constructed from four questions from the Cohen Perceived Stress Scale, and suicidal thoughts, an indicator for people who report that they have thought seriously about committing suicide during the 
last 12 months. Accountants is an indicator variable for accountants. Income is personal income in 2016 dollars. Prestige is a score from 1 to 10 representing where a person feels they sit on a ladder representing "where people stand in the United States" in terms of the most money, education, and respected jobs. Hours worked is the number of hours typically worked in a week. Long hours is an indicator for people who work more than 55 hours a week. Irregular hours is an indicator for people who report working rotating or irregular shifts. Free to make decisions is an indicator variable for people who feel that they are free to make decisions at work. Work repetitive is an indicator for people who feel that their job is repetitive. High school graduate, bachelor's degree, master's degree, doctorate, and professional degree are indicator variables for respondents' highest degrees. Female is an indicator variable for women. Childhood income is an estimate of family income when the respondent was an adolescent. Family interferes work and work interferes family are indicator variables for people who feel that work and family interfere with one another. Daily prayer is an indicator variable for people who pray at least daily. Weekly church is an indicator variable for people who attend church at least weekly. Close friends is a measure of the number of close friends a person has. Excessive drinking is an indicator variable for people whose drinking behavior meets the CDC's definition of excessive drinking. Marijuana is an indicator variable for marijuana users. Drugs is an indicator for users of other illegal drugs. Neurotic, extraverted, conscientious, open, and agreeable personality are the "big-5" personality traits. Childhood depression, suicidal thoughts, and suicide attempts are indicator variables for people who had these experiences during childhood. Childhood fam/friend suicide is an indicator for people who, as children, were close to a person who committed suicide. Childhood friends care, and parents care are indicator variables for people who felt as adolescents that their friends or parents cared about them. Childhood physical abuse, and sexual abuse are indicators for people who, as adults, report that they were abused as children. Stars represent statistically significant two-tailed differences at the $\mathrm{p}<0.01(* * *), 0.05(* *)$, and $0.10(*)$ levels. Detailed variable definitions are in the appendix. 